\title{
Nitrogen Limitation of the Summer Phytoplankton and Heterotrophic Prokaryote Communities in the Chukchi Sea
}

OPEN ACCESS

Edited by:

Claire Mahaffey,

University of Liverpool,

United Kingdom

Reviewed by:

Allison A. Fong,

Alfred-Wegener-Institut, Helmholtz-Zentrum für Polar-und Meeresforschung (HZ), Germany

Jun Sun,

Tianjin University of Science and Technology, China

${ }^{*}$ Correspondence: Matthew M. Mills mmmills@stanford.edu

Specialty section:

This article was submitted to Marine Biogeochemistry,

a section of the journal

Frontiers in Marine Science

Received: 06 July 2018 Accepted: 20 September 2018 Published: 15 October 2018

Citation:

Mills MM, Brown ZW, Laney SR Ortega-Retuerta E, Lowry KE, van Dijken GL and Arrigo KR (2018) Nitrogen Limitation of the Summer Phytoplankton and Heterotrophic Prokaryote Communities in the Chukchi Sea.

Front. Mar. Sci. 5:362. doi: 10.3389/fmars.2018.00362

\author{
Matthew M. Mills ${ }^{*}$, Zachary W. Brown ${ }^{2}$, Samuel R. Laney ${ }^{3}$, Eva Ortega-Retuerta ${ }^{4}$, \\ Kate E. Lowry ${ }^{3}$, Gert L. van Dijken ${ }^{1}$ and Kevin R. Arrigo' ${ }^{1}$ \\ ${ }^{1}$ Department of Earth System Science, Stanford University, Stanford, CA, United States, ${ }^{2}$ Inian Islands Institute, Gustavus, \\ AK, United States, ${ }^{3}$ Biology Department, Woods Hole Oceanographic Institution, Woods Hole, MA, United States, \\ ${ }^{4}$ Laboratoire d'Océanographie Microbienne, Observatoire Océanologique, CNRS, Sorbonne Université, UMR 7621, \\ Banyuls-sur-Mer, France
}

Major changes to Arctic marine ecosystems have resulted in longer growing seasons with increased phytoplankton production over larger areas. In the Chukchi Sea, the high productivity fuels intense benthic denitrification creating a nitrogen $(N)$ deficit that is transported through the Arctic to the Atlantic Ocean, where it likely fuels $N$ fixation. Given the rapid pace of environmental change and the potentially globally significant $\mathrm{N}$ deficit, we conducted experiments aimed at understanding phytoplankton and microbial $\mathrm{N}$ utilization in the Chukchi Sea. Ship-board experiments tested the effect of nitrate $\left(\mathrm{NO}_{3}{ }^{-}\right)$ additions on both phytoplankton and heterotrophic prokaryote abundance, community composition, photophysiology, carbon fixation and $\mathrm{NO}_{3}{ }^{-}$uptake rates. Results support the critical role of $\mathrm{NO}_{3}{ }^{-}$in limiting summer phytoplankton communities to small cells with low production rates. $\mathrm{NO}_{3}{ }^{-}$additions increased particulate concentrations, abundance of large diatoms, and rates of carbon fixation and $\mathrm{NO}_{3}{ }^{-}$uptake by cells $>1 \mu \mathrm{m}$. Increases in the quantum yield and electron turnover rate of photosystem II in $+\mathrm{NO}_{3}{ }^{-}$ treatments suggested that phytoplankton in the ambient dissolved $\mathrm{N}$ environment were $\mathrm{N}$ starved and unable to build new, or repair damaged, reaction centers. While some increases in heterotrophic prokaryote abundance and production were noted with $\mathrm{NO}_{3}{ }^{-}$ amendments, phytoplankton competition or grazers likely dampened these responses. Trends toward a warmer more stratified Chukchi Sea will likely enhance summer oligotrophic conditions and further N starve Chukchi Sea phytoplankton communities.

Keywords: phytoplankton, nitrogen, Chukchi Sea, nitrate, nutrient limitation

\section{INTRODUCTION}

The Arctic Ocean is currently undergoing massive alterations due to global climate change. Of paramount importance is the loss of sea ice. Annual mean open water area has increased $\sim 2.8 \% \mathrm{yr}^{-1}$ between 1998 and 2012 (Arrigo and van Dijken, 2015), and evidence suggests the trend will continue, with the monthly average ice extent for September decreasing $13.3 \%$ per decade relative to the 1981-2010 average (Perovich et al., 2016). The primary contributors to the increasing loss of ice are higher global temperatures due to greenhouse gas emissions (Zhang and Walsh, 2006; 
Stroeve et al., 2007), increased warm water input to the Arctic from both the Pacific and Atlantic Oceans (Spielhagen et al., 2011; Woodgate et al., 2012), and an increase of ice flowing out of the Arctic to the Atlantic (Smedsrud et al., 2017). The loss of sea ice in the Arctic decreases albedo and results in further warming of the ocean, which perpetuates additional loss of ice. Evidence suggests that the loss of sea ice in the Arctic is consistent with this ice albedo feedback cycle (Perovich et al., 2007, 2011), with the number of open water days increasing over time (Arrigo and van Dijken, 2015).

Coincident with increased open water area across the Arctic Ocean has been a $30 \%$ increase in net primary production (NPP) between 1998 and 2012 as greater areas of the ocean are exposed to light, thereby facilitating more rapid phytoplankton growth (Arrigo and van Dijken, 2015). However, in addition to light, phytoplankton growth requires nutrients, and thus the increase in Arctic NPP may also be coincident with an increase in nutrient availability. Flow through the Bering Strait has increased between 2001 and 2011 (Woodgate et al., 2012) and is a possible source of new nutrients to the Arctic Ocean. Likewise, increased input from rivers may supply useable nutrients for phytoplankton (Ardyna et al., 2014). Finally, shelf break upwelling can entrain nutrients into surface waters (Spall et al., 2014), and an increase in this process would likely increase NPP as well. Which, if any, of these processes are contributing to the higher NPP in the Arctic Ocean is unclear.

The flow of water within the Chukchi Sea is to first order dictated by the bathymetry of the shelf (Weingartner et al., 2005; Spall, 2007; Pickart et al., 2016). Three main pathways emanate northward from the Bering Strait (Figure 1): a western branch that goes through Herald Canyon, a middle branch that progresses through the Central Channel (the gap between Herald Shoal and Hanna Shoal), and an eastern branch that flows adjacent to the coast of Alaska. In summertime, the eastern branch is known as the Alaskan Coastal Current (ACC), which transports relatively warm and fresh Alaskan Coastal Water (ACW) originating from coastal runoff in the Gulf of Alaska and Bering Sea. The middle branch is believed to transport a combination of Bering Shelf Water (BSW) and Anadyr Water (AW), which ultimately mix to form Bering and Chukchi Summer Water (BCSW). The western branch is thought to advect primarily AW. The ACC is typically warm $\left(>2^{\circ} \mathrm{C}\right.$, Figure 1$)$, depleted in nutrients, and has a significant contribution from river input (Weingartner et al., 2013; Gong and Pickart, 2016). In contrast, the summertime BCSW is generally colder $(-1$ to $2^{\circ} \mathrm{C}$ ) than the ACW and has higher nutrient concentrations. Some fraction of the AW in the western flow branch is diverted eastward toward the BCSW (e.g., Pickart et al., 2010) and the combined flow is then steered around Hanna Shoal toward Barrow Canyon. Recently, the Central Channel flow path was shown to bifurcate and pass around both sides of Hanna Shoal prior to flowing into Barrow Canyon (Pickart et al., 2016). As such, all three Pacific water masses primarily exit the Chukchi Sea through Barrow Canyon (Gong and Pickart, 2015).

In early winter, ice formation and brine rejection over the Chukchi shelf drive convective overturning that mixes the water column. As winter progresses, the whole of the Chukchi Sea becomes ice covered, daylight disappears, and inorganic nutrient concentrations increase due in part to microbial net remineralization of organic matter. The combination of the brine-induced mixing and nutrient regeneration results in a fully mixed, nutrient-rich water column, known as winter water
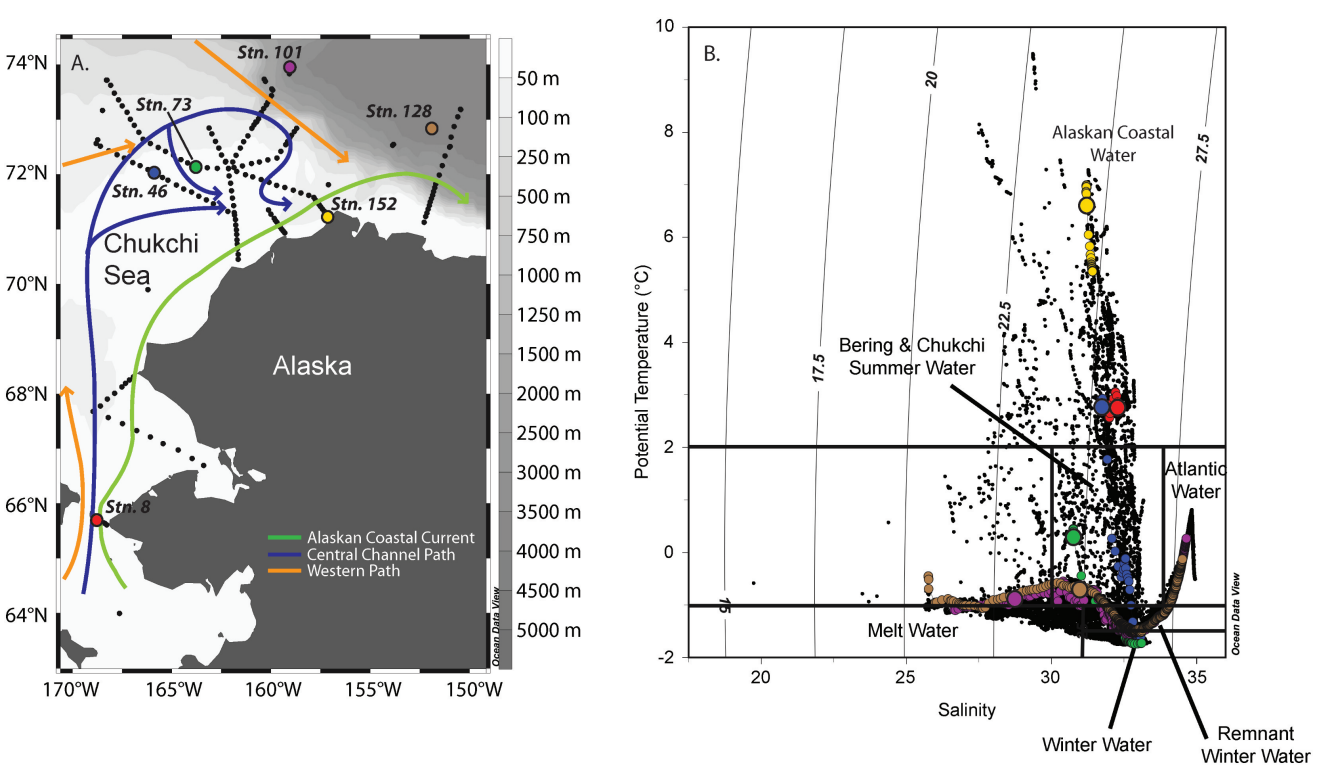

FIGURE 1 | Map of the Chukchi Sea showing the stations sampled during the ICESCAPE 2011 field campaign (A). Stations where nutrient addition bioassays were carried out are shown as colored dots. Temperature (T) and salinity (S) relationship of waters sampled during ICESCAPE 2011. Vertical lines indicate water mass density (B). The colored dots represent profiles at stations where nutrient addition bioassay were conducted, where colors match the stations in (A). The largest dot in each profile is T-S of the sampled depth. 
(WW), that persists until ice melt begins in the spring (Arrigo et al., 2017), when light levels are high enough for phytoplankton to draw down nutrients and begin fixing carbon (Lowry et al., 2018). In recent years, thinner ice with high melt pond fractions have increased light penetration into the water below, allowing phytoplankton to bloom and consume nutrients even when sea ice is still present (Arrigo et al., 2012, 2014).

With respect to nutrient limitation, nitrogen $(\mathrm{N})$ is considered the nutrient that limits autotrophic productivity in the Arctic once the spring bloom is complete (Kattner and Budeus, 1997; Tremblay et al., 2002, 2008; Simpson et al., 2008; Tremblay and Gagnon, 2009). Likewise, Ortega-Retuerta et al. (2012) demonstrated that heterotrophic prokaryotes were $\mathrm{N}$-limited in the Western Arctic Ocean. The low concentrations of inorganic $\mathrm{N}$ relative to dissolved inorganic phosphorus (DIP) and dissolved silica (DSi) are primarily the result of high rates of denitrification in the sediments of the Bering Sea and Chukchi shelf that reduce nitrate $\left(\mathrm{NO}_{3}{ }^{-}\right)$and nitrite $\left(\mathrm{NO}_{2}{ }^{-}\right)$to the gaseous products nitric oxide (NO), nitrous oxide $\left(\mathrm{N}_{2} \mathrm{O}\right)$, and dinitrogen gas $\left(\mathrm{N}_{2}\right)$ (Devol et al., 1997; Chang and Devol, 2009; Brown et al., 2015). A recent study (Mills et al., 2015) showed that excess $\mathrm{N}\left(N^{* *}\right)$ decreased from the south to the north over the Chukchi Shelf, an indication that denitrification had removed $\mathrm{N}$ from the water during transit. Estimates of denitrification in the Arctic suggest it is a globally important N sink (Chang and Devol, 2009; Mills et al., 2015).

Phytoplankton can acclimate to $\mathrm{N}$ limitation in multiple ways. One primary response is to reduce the cell quota for $\mathrm{N}$ by lowering the amount of $\mathrm{N}$-containing chlorophyll $a(\mathrm{Chl} a)$ per cell. Likewise, cells can reduce the cellular concentration of protein-rich light harvesting complexes, as well as other components of the photosynthetic electron transport chain that are composed of $\mathrm{N}$-rich proteins. However, decreasing the size of the antennae that captures photons has the disadvantage that it either reduces the functional absorption cross section ( $\sigma_{\text {PSII }}$ ) or decreases the number of photosystem components, thereby reducing the rate at which electrons can flow through the photosynthetic electron transport chain $\left(1 / \tau_{\text {PSII }}\right)$ (Moore et al., 2006; Lewis et al., 2018). Another phytoplankton response to $\mathrm{N}$ limitation may be an increase in $\mathrm{NO}_{3}^{-}$transporters (Hildebrand and Dahlin, 2000) which likely leads to increased $\mathrm{N}$ uptake rates when $\mathrm{NO}_{3}^{-}$becomes available. However, other data suggest transporter numbers per cell are constant whether $\mathrm{N}$ is limiting or not (Zehr et al., 1988). In addition to changes in transporter proteins, N-limited phytoplankton cells have increased protease activities and decreased protein concentrations, particularly the carbon fixation enzyme ribulose 1,5-bisphosphate carboxylase/oxygenase (Berges and Falkowski, 1998).

The composition of the phytoplankton community can also change upon depletion of nutrients. Typically, the community shifts toward smaller cells more adapted to low nutrient concentrations (Moore et al., 2013). Smaller cells have a higher surface area to volume ratio and lower nitrogen requirements, and thus a competitive advantage under low nutrient conditions. Evidence in the Arctic shows that as the freshwater content has increased, nutrient availability has decreased and phytoplankton communities are shifting toward smaller cells (Li et al., 2009;
Lee et al., 2013). If trends of decreasing ice concentrations and increasing sea surface temperatures continue for the Arctic Ocean, a potential future could include a more stratified water column with less available nutrients for phytoplankton and heterotrophic prokaryotes. As such, the shift toward smaller phytoplankton cells described in Li et al. (2009) would be expected to continue and become more widespread.

Given the current Arctic Ocean environmental changes, we designed the present study with the objective of gaining a better understanding of how phytoplankton and heterotrophic prokaryotes currently utilize $\mathrm{NO}_{3}{ }^{-}$in the Chukchi Sea. As such, we tested the response of the phytoplankton and heterotrophic prokaryote communities to additions of $\mathrm{NO}_{3}{ }^{-}$, and followed changes in nutrient concentrations, bulk Chl $a$, and active fluorescence. Additionally, we measured changes in the abundance of the $\sim<10 \mu \mathrm{m}$ sized phytoplankton cells, taxon-specific $\mathrm{C}$ content of phytoplankton $\sim>\mu \mathrm{m}$, size fractionated $(<1 \mu \mathrm{m}$ and $>1 \mu \mathrm{m})$ particulate organic $\mathrm{N}$ and carbon (C), and $\mathrm{NO}_{3}{ }^{-}$and $\mathrm{CO}_{2}$ uptake rates. Finally, we measured changes in the abundance and production of the heterotrophic prokaryote populations. The results are discussed with respect to how predicted changes in the Western Arctic Ocean will affect phytoplankton and heterotrophic prokaryote communities and their impact on the biogeochemistry of the region.

\section{MATERIALS AND METHODS}

\section{Study Site and Sampling Locations}

Between June 25 and July 29, 2011, six nutrient addition bioassays were conducted in the Chukchi Sea as a part of the Impacts of Climate on EcoSystems and Chemistry of the Arctic Pacific Environment (ICESCAPE) field campaign (Figure 1A). Experiments were conducted at four on-shelf and two off-shelf stations. The experiments were conducted in three different surface water masses (Figure 1B), including ACW (Stations 8, 46, and 152), BCSW (Station 73), and off-shelf meltwater-influenced waters (Stations 101 and 128).

\section{$\mathrm{NO}_{3}{ }^{-}$Addition Experiments}

Seawater was collected from the upper mixed layer at all stations using a CTD rosette outfitted with twelve $30 \mathrm{~L}$ Niskin bottles. Water was sampled from within the mixed layer at all sites except the two farthest offshore (Stns. 101 and 128) (Table 1). Mixed layer depth (MLD) was determined as in Palmer et al. (2013). Once onboard, water was randomly dispensed into $2 \mathrm{~L}$ acid-washed polycarbonate bottles through $100 \mu \mathrm{m}$ Nitex mesh to remove grazers. The experiments were not intended to quantify grazers or grazing rate and thus they were removed from both treatments to isolate the effect of $\mathrm{NO}_{3}{ }^{-}$ on the phytoplankton and heterotrophic prokaryote community. Triplicate bottles were filled for two treatments (control and $+\mathrm{NO}_{3}{ }^{-}$) and 5-7 sampling time points. The $+\mathrm{NO}_{3}{ }^{-}$bottles were amended with $\mathrm{NO}_{3}{ }^{-}$such that final concentrations were $\sim 5 \mathrm{mmol} \mathrm{NO}_{3}-\mathrm{m}^{-3}$, except at station 8 where the $\mathrm{NO}_{3}{ }^{-}$ amendment resulted in a final concentration of $\sim 10 \mathrm{mmol} \mathrm{m}^{-3}$. 


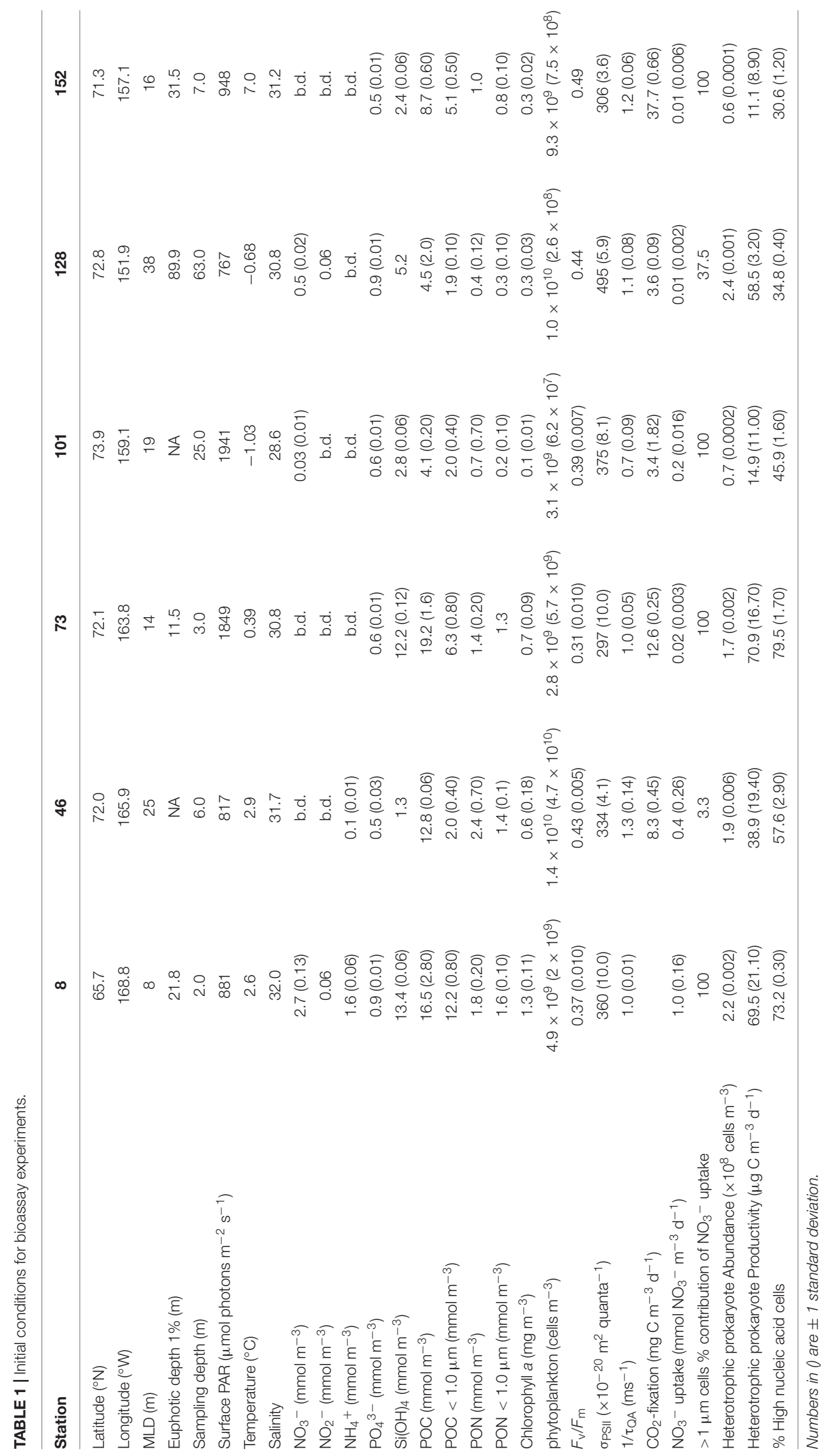


The bottles were sealed and placed in on-deck flow-through incubators cooled with surface seawater and shaded to $50 \%$ of incident irradiance using neutral density screening. Triplicate bottles of each treatment were analyzed at multiple sampling time ( $T$ ) points $(T=0,24,48,72$, and $96 \mathrm{~h})$. At the two off the shelf stations (Stations 101 and 128), samples were also collected at $T=120$ and $144 \mathrm{~h}$. Incubation times were relatively long because sea surface temperatures were low $\left(-1.0-2.9^{\circ} \mathrm{C}\right)$ at all sites except one (St. 152) (Table 1) and phytoplankton growth rates were expected to be low.

Samples were collected at each time point for the measurement of nutrient concentrations $\left[\mathrm{NO}_{3}{ }^{-}, \mathrm{NO}_{2}{ }^{-}\right.$, $\left.\mathrm{NH}_{4}{ }^{+}, \mathrm{PO}_{4}{ }^{3-}, \mathrm{Si}(\mathrm{OH})_{4}\right]$, Chl a concentration, maximum photochemical efficiency of PSII $\left(F_{\mathrm{v}}: F_{\mathrm{m}}\right)$, effective optical cross section of PSII ( $\sigma_{\text {PSII }}$ ), turnover time of the primary electron acceptor at PSII $\left(\tau_{\mathrm{Qa}}\right)$, phytoplankton cell abundance $(\sim<10 \mu \mathrm{m})$ and heterotrophic prokaryote abundance and production. At the initial and final time points, size fractionated samples ( $<1.0 \mu \mathrm{m}$ and total community fractions) were also collected for quantification of particulate organic carbon and nitrogen (POC and PON) concentrations and $\mathrm{CO}_{2}$ fixation and $\mathrm{NO}_{3}{ }^{-}$uptake rates. Finally, the $\mathrm{C}$ content of the most abundant phytoplankton taxa $(\sim>8 \mu \mathrm{m})$ was measured as described in Laney and Sosik (2014).

\section{Nutrient Analysis}

Nutrient samples were analyzed on a segmented continuous flow autoanalyzer (AA3, Seal Analytical) within an hour of collection. $\mathrm{NO}_{3}{ }^{-}+\mathrm{NO}_{2}{ }^{-}$and $\mathrm{Si}(\mathrm{OH})_{4}$ concentrations were determined using a modification of the Armstrong et al. (1967) methods. $\mathrm{NH}_{4}{ }^{+}$concentrations were determined fluorometrically (Kerouel and Aminot, 1997). $\mathrm{PO}_{4}{ }^{3-}$ concentrations were measured using the ammonium molybdate method described in Bernhardt and Wilhelms (1967). It should be noted that all nutrients were measured on unfiltered seawater which can impact measured concentrations when particulate loads are high due to nutrient release from particles. For the most part, surface nutrients were depleted, indicating that our sampling was after the major growth season and consequently, particulate loads were low.

\section{Particulate Analysis}

Samples for fluorometric analysis of Chl $a$ were filtered onto $25 \mathrm{~mm}$ Whatman GF/F filters (nominal pore size $0.7 \mu \mathrm{m}$ ), placed in $5 \mathrm{~mL}$ of $90 \%$ acetone, and extracted in the dark at $3^{\circ} \mathrm{C}$ for $24 \mathrm{~h}$. Chl $a$ was measured fluorometrically (HolmHansen et al., 1965) using a Turner Fluorometer 10-AU (Turner Designs, Inc.). POC and PON samples were size-fractionated by filtering samples onto 0.2 and $1.0 \mu \mathrm{m}$ silver filters (Sterlitech Corporation). Blank filters for each size fraction were made by passing $\sim 25 \mathrm{ml}$ of $0.2 \mu \mathrm{m}$ filtered seawater over the respective pore-sized silver filters and processed the same as the particulate samples. The filters were immediately dried at $60^{\circ} \mathrm{C}$ and stored dry until processing. Prior to analysis, the samples were fumed with concentrated $\mathrm{HCl}(37 \%)$ for $\sim 12 \mathrm{~h}$, dried $\left(60^{\circ} \mathrm{C}\right)$, and packed into tin capsules (Costech Analytical Technologies, Inc.) for analysis on an Elementar Vario EL Cube or Micro Cube elemental analyzer (Elementar Analysensysteme GmbH, Hanau, Germany) interfaced to a PDZ Europa 20-20 isotope ratio mass spectrometer (Sercon Ltd., Cheshire, United Kingdom). Peach leaves and glutamic acid were used as calibration standards. The limits of detection for POC and PON, calculated as three times the standard deviation of the average blank filters, were 1.8 and $18 \mu \mathrm{g} \mathrm{N}$ and $\mathrm{C}$, respectively.

\section{Phytoplankton and Heterotrophic Prokaryote Abundance}

A flow cytometer (Accuri C6, Becton-Dickson) was used to determine the abundance of phytoplankton $<10 \mu \mathrm{m}$. A detailed description of the flow cytometric protocols used here is outlined in Laney and Sosik (2014). Briefly, seawater samples were prefiltered through Nitex screening (200 $\mu \mathrm{m}$ mesh size) to remove larger cells, chains, and colonies that might clog the instrument flow cell. For phytoplankton cells, approximately $200 \mu \mathrm{l}$ of sample were counted. Distilled water blanks were measured after each set of samples at every station, and standard beads (PeakFlow P14827, $2.5 \mu \mathrm{m}, 515 \mathrm{~nm}$ emission) were also run periodically during the cruise to track instrument behavior, to determine the instrument sensitivity in detecting cells or other particles, and to provide reference data for normalizing the phytoplankton cell scattering measurements into bead units. Custom software was used to interpret the measured cell scattering and fluorescence data and determine the abundance of $<10 \mu \mathrm{m}$ cells. Phytoplankton cells were discriminated from other particles by their relative combinations of chlorophyll fluorescence and side scattering. Phytoplankton taxa $(\sim>8 \mu \mathrm{m})$ were enumerated using an Imaging FlowCytobot (IFCB) as described in Laney and Sosik (2014). The IFCB uses a combination of flow cytometric and video technology to capture high-resolution images of phytoplankton in the nano- and micro-size fraction (Olson and Sosik, 2007). Briefly, seawater samples $(5 \mathrm{ml})$ were injected through an $860 \mu \mathrm{m} \times 180 \mu \mathrm{m}$ flow cell through which a $635 \mathrm{~nm}$ laser beam was focused. Chl $a$-containing particles that passed through this beam emitted a fluorescence signal that triggered the digital camera capturing a micrograph of that particular cell, chain, or colony. A Nitex screen (nominal mesh size $130 \mu \mathrm{m}$ ) placed on the sample intake prevented large particles from clogging the flow cell. This screen, combined with the camera field of view, set the effective upper size limit of cells, chains, or colonies to a length $<\sim 300 \mu \mathrm{m}$. The lower size limit of cells was a function of the minimum fluorescence intensity needed to trigger the camera, typically $>8$ $\mu \mathrm{m}$. The cells imaged using the IFCB allowed for quantification of different taxa in the $>8 \mu \mathrm{m}$ size class. Additionally, non-algal classes such as detritus and diatom frustules were also identified in images where present. Using the same methods presented in Laney and Sosik (2014), the data were converted to equivalent C units for each taxonomic group.

Heterotrophic prokaryotes were counted on board using a $488 \mathrm{~nm}$ laser on the flow cytometer. Samples were fixed with glutaraldehyde $(0.25 \%$ final concentration $)$ and stored at $-80^{\circ} \mathrm{C}$ until processing (within a few days after collection). Samples were thawed and SYBR Green-I was added at a final dilution of $1: 10,000$. Samples were incubated in the dark for $15 \mathrm{~min}$ before 
analysis. Heterotrophic prokaryotes were identified on a plot of green fluorescence (515-545 nm) versus right-angle light scatter (SSC), using the green fluorescence as a threshold parameter. The prokaryote population was sorted into the commonly grouped high nucleic acid (HNA) and low nucleic acid (LNA) containing cells (Gasol and Del Giorgio, 2000) according to their green fluorescence and counted separately (Marie et al., 1997).

\section{FRRf Measurements}

The bulk $F_{\mathrm{v}}: F_{\mathrm{m}}, \sigma_{\text {PSII }}$, and $1 / \tau_{\mathrm{Qa}}$ of the phytoplankton community was measured on dark-acclimated (30 min.) aliquots of initial and treated waters using a Light Induced Fluorescence Transients Fast Repetiton Rate fluorometer (LIFT-FRRf ${ }^{1}$ ). Briefly, the sample chamber was exposed to a FRRf excitation protocol composed of a series of microsecond-long flashlets of controlled excitation power. The saturation phase of the excitation was comprised of 100 flashlets at $2.5 \mathrm{~ms}$ intervals. With the pulse excitation power of 30,000-50,000 $\mu \mathrm{mol}$ quanta $\mathrm{m}^{-2} \mathrm{~s}^{-1}$, the rate of excitation delivery to PSII centers far exceeded the capacity of photosynthetic electron transport between PSII and PSI. This resulted in a progressive saturation of the observed fluorescence transients within the first 40-60 flashlets, at a rate proportional to the functional absorption cross section. The saturation phase was followed by 90 flashlets applied at exponentially increasing time intervals starting at $20 \mathrm{~ms}$, over a period of $250 \mathrm{~ms}$. As the average excitation power decreased, the fluorescence signal relaxed with kinetics mostly defined by the rate of electron transport between PSII and PSI. Each sample measurement consisted of an average of 32 transients, and each sample was measured three times. Blanks for individual samples analyzed by FRRf were prepared by gentle filtration through a $0.2 \mathrm{~mm}$ polycarbonate syringe filter before measurement using identical protocols. All reported values were corrected for blank effects (Cullen and Davis, 2003). Recorded fluorescence transients were processed with FRRf software ${ }^{1}$ to estimate $F_{\mathrm{m}}, F_{\mathrm{V}} / F_{\mathrm{m}}$, $\sigma_{\mathrm{PSII}}$, and $1 / \tau_{\mathrm{Qa}}$ for all Chl $a$-containing cells (excitation wavelength of $470 \mathrm{~nm})$.

\section{Rate Measurements}

Samples for the determination of ${ }^{14} \mathrm{CO}_{2}$-fixation and $\mathrm{NO}_{3}{ }^{-}$ uptake rates were measured at $T=0$ and $T=$ final. ${ }^{14} \mathrm{CO}_{2}$ fixation rates were determined by measuring ${ }^{14} \mathrm{C}$-incorporation in subsamples collected from the triplicate control and $\mathrm{NO}_{3}{ }^{-}$ amended bottles. To $150 \mathrm{~mL}$ of sample, $0.74 \mathrm{MBq}$ of $\mathrm{H}^{14} \mathrm{CO}_{3}$ was added and incubated in the on-deck incubators at 50\% incident irradiance for $24 \mathrm{~h}$. After incubation, $30 \mathrm{~mL}$ was filtered onto $25 \mathrm{~mm}$ GF/F filters in triplicate under very low vacuum pressure $(<2.5 \mathrm{~mm} \mathrm{Hg})$. The filters were transferred to glass scintillation vials acidified with $0.1 \mathrm{~mL}$ of $6 \mathrm{~N} \mathrm{HCl}$ and allowed to sit over the next $24 \mathrm{~h}$ to drive off unincorporated inorganic $\mathrm{C}$. After the acidification step, $5 \mathrm{~mL}$ of scintillation cocktail (Ecolume) was added to each sample, which were counted (after $>3 \mathrm{~h}$ ) on a PerkinElmer Tri-Carb liquid scintillation counter. Total activity was determined on each sample by combining $50 \mu \mathrm{L}$ of sample with $50 \mu \mathrm{L}$ of ethanolamine, $0.5 \mathrm{~mL}$ filtered seawater, and $5 \mathrm{~mL}$

${ }^{1}$ http://soliense.com/ of scintillation cocktail. $T=0$ samples were filtered $(30 \mathrm{~mL}$ in triplicate) and acidified at the start of the incubation period. Rates of $\mathrm{CO}_{2}$ fixation were then calculated as outlined in Knap et al. (1996).

Initial and final $\mathrm{NO}_{3}{ }^{-}$uptake rates were determined by measuring the incorporation of ${ }^{15} \mathrm{NO}_{3}{ }^{-}$into the total and $>1 \mu \mathrm{m}$ particulate matter fractions. At each time point, a $20 \mathrm{~mL}$ sample was collected to determine the concentration of $\mathrm{NO}_{3}{ }^{-}$in the $2 \mathrm{~L}$ experiment bottles and then trace additions $(\sim 10 \%$ of ambient $\left[\mathrm{NO}_{3}{ }^{-}\right]$) of $99 \% \mathrm{Na}^{15} \mathrm{NO}_{3}$ were made to each bottle. Immediately following this spike, subsamples collected from each bottle were filtered onto silver filters $(0.2$ or $1.0 \mu \mathrm{m}$ pore size for the total and $>1.0 \mu \mathrm{m}$ size fractions, respectively) for determination of the $T=0$ atom $\%{ }^{15} \mathrm{~N}$. The spiked bottles were returned to their incubators for $24 \mathrm{~h}$ after which subsamples were collected onto silver filters, as done at the start of rate measurement. All filters were prepared for analysis in the same manner as the POC/PON filters. All enriched isotope analyses took place on a Micro Cube elemental analyzer (Elementar Analysensysteme $\mathrm{GmbH}$, Hanau, Germany) interfaced to a PDZ Europa 20-20 isotope ratio mass spectrometer (Sercon Ltd., Cheshire, United Kingdom). The isotopic enrichment of each sample was determined as atom $\%{ }^{15} \mathrm{~N}$ where atom $\%{ }^{15} \mathrm{~N}=\frac{{ }^{15} \mathrm{~N}}{{ }^{14} N+{ }^{15} \mathrm{~N}}$ and $\mathrm{NO}_{3}{ }^{-}$uptake rates were determined as in Glibert and Capone (1993). The limit of detectable enrichment $(0.04 \%)$ was determined as three times the standard deviation of the $T=0$ samples.

Heterotrophic prokaryote production (BP) was measured by ${ }^{3} \mathrm{H}$-leucine incorporation (Smith and Azam, 1992). Samples ( $1.5 \mathrm{~mL}$ in triplicate plus one killed control) were added to sterile microcentrifuge tubes containing 20-30 nM [4,5-3 H]-leucine. This concentration was sufficient to saturate heterotrophic prokaryote leucine uptake. Incorporation rates were measured after $2 \mathrm{~h}$ incubations at in situ temperature and incubations were stopped by the addition of trichloroacetic acid (5\% final concentration). The mean sample dpm was on average 4.4fold greater than the mean blank dpm. Contamination was not detected in the leucine batches. Leucine incorporation rates were converted to $\mathrm{C}$ production using the conversion factor of $1.5 \mathrm{~kg}$ C produced per mole leucine incorporated (Kirchman, 1993), assuming no isotope dilution.

\section{Comparison Between Experiments}

The similarity of responses between the different experiments were analyzed by comparing the treatment to the control response at $T=$ final for multiple variables. Hierarchical clustering using Ward's minimum variance method was used to group experiments with similar relative responses. Visualization of the relative responses and the hierarchical clustering were calculated using RStudio v.1.1.453 and the gplots and ggdendro packages.

\section{RESULTS}

\section{Initial Conditions}

The initial starting conditions were partially dictated by where on the shelf, and thus in what water mass, the experimental 
water was collected (Figure 1B). The temperature and salinity relationships indicate that surface waters at Stns. 8, 46, and 152 were ACW. Of these, the coastal Stn. 152 was the warmest $\left(\sim 7^{\circ} \mathrm{C}\right)$, with both Stns. 8 and 46 being approximately $4^{\circ} \mathrm{C}$ cooler. While the entire water column was well mixed at Stn. 8 , the same was not true at Stn. $46(\mathrm{MLD}=25 \mathrm{~m}$, Table 1) where surface ACW overlaid a BCSW layer and a WW bottom layer. Stratification at Stn. 152 was relatively weak, with only a 0.25 difference in salinity between the surface and bottom water. The surface water at Station 73 was a shallower $(\mathrm{MLD}=14 \mathrm{~m})$ BCSW layer while the bottom layer was WW. Finally, the two stations located furthest north, at the shelf break (Stn. 101, MLD = $19 \mathrm{~m}$ ) and off the shelf (Stn. 128, MLD = $38 \mathrm{~m}$ ), were characterized by low salinity meltwater at the surface overlying BCSW and WW (Figure 1B).

Significant concentrations of dissolved inorganic nitrogen (DIN) were detected only at Stn. 8 (Bering Strait) and Stn. 128 (off-shelf easternmost site) (Table 1 and Figure 1A). At the Bering Strait station, both $\mathrm{NO}_{3}{ }^{-}\left(2.7 \pm 0.3 \mathrm{mmol} \mathrm{m}{ }^{-3}\right.$, mean $\pm \mathrm{SD})$ and $\mathrm{NH}_{4}{ }^{+}\left(1.6 \pm 0.6 \mathrm{mmol} \mathrm{m}^{-3}\right)$ concentrations were relatively high, while at Stn. 128, detectable $\mathrm{NO}_{3}{ }^{-}$ concentrations $\left(0.5 \pm 0.02 \mathrm{mmol} \mathrm{m}^{-3}\right)$ were measured only in relatively deep $(63 \mathrm{~m})$ waters. At the sampling depth at all other stations, the DIN concentrations were below or at the limit of detection of our instrument. In contrast, $\mathrm{PO}_{4}{ }^{3-}$ was detectable at all sites, and as with DIN, Stns. 8 and 128 had the highest concentrations $\left(0.9 \mathrm{mmol} \mathrm{m}^{-3}\right)$ (Table 1). $\mathrm{Si}(\mathrm{OH})_{4}$ was also detectable at all stations, with Stn. 8 having the highest concentrations $\left(13.4 \pm 0.06 \mathrm{mmol} \mathrm{m}^{-3}\right)$. Similarly, high concentrations of $\mathrm{Si}(\mathrm{OH})_{4}$ were measured at the shelf $\mathrm{Stn} .73$ $\left(12.2 \pm 0.12 \mathrm{mmol} \mathrm{m}^{-3}\right)$, while at the remaining stations, initial $\mathrm{Si}(\mathrm{OH})_{4}$ concentrations ranged between 1.3 and $5.2 \mathrm{mmol} \mathrm{m}^{-3}$.

The initial concentrations of Chl $a$ in waters used for the experiments ranged from 0.1 to $1.3 \mathrm{mg} \mathrm{m}^{-3}$, being highest at the southernmost Bering Strait station $\left(1.3 \pm 0.11 \mathrm{mg} \mathrm{m}^{-3}\right)$ and generally decreasing northward (Table 1). Additionally, initial Chl a concentrations were significantly correlated to $\mathrm{Si}(\mathrm{OH})_{4}$ concentrations [slope $=0.6 \mu \mathrm{g} \mathrm{Chl} a \mu \mathrm{mol}^{-1} \mathrm{Si}(\mathrm{OH})_{4}, r=0.78$, $p<0.05$ ], although not to other dissolved nutrient pools. Autotrophic cell abundance showed no trends with latitude. Concentrations of POC and PON were higher at the shelf stations relative to the two northern off-shelf stations (Stns. 102 and 128).

$F_{\mathrm{v}}: F_{\mathrm{m}}$ of initial samples ranged approximately 1.5 -fold, from 0.31 to 0.49 , while $\sigma_{\text {PSII }}$ ranged 1.6 -fold $\left(297-495 \times 10^{-20} \mathrm{~m}^{2}\right.$ quanta $\left.^{-1}\right)$ and $1 / \tau_{\mathrm{QA}}$ ranged 1.9 -fold $\left(0.7-1.3 \mathrm{~ms}^{-1}\right)$. Neither $F_{\mathrm{v}}: F_{\mathrm{m}}, \sigma_{\mathrm{PSI}}$, nor $1 / \tau_{\mathrm{QA}}$ changed systematically with either latitude, surface irradiance, or nutrient concentrations. However, both $F_{\mathrm{v}}: F_{\mathrm{m}}$ and $\sigma_{\text {PSII }}$ increased significantly with $\operatorname{MLD}\left(F_{\mathrm{v}}: F_{\mathrm{m}}\right.$ vs. MLD: $m=0.003 \mathrm{~m}^{-1}, r=0.63, p<0.05$; $\sigma_{\text {PSII }}$ vs. MLD: $\left.m=4.6 \times 10^{-20} \mathrm{~m} \mathrm{quanta}^{-1}, r=0.77, p<0.05\right)$. There was no relationship between $1 / \tau_{\mathrm{QA}}$ and MLD.

$\mathrm{CO}_{2}$ fixation rates of the initial samples were highest at the inshore coastal station (Stn. 152: $37.7 \pm 0.66 \mathrm{mg} \mathrm{C} \mathrm{m}^{-3} \mathrm{~d}^{-1}$ ) followed by the two mid-shelf stations (Stn. $46: 8.3 \pm 0.45 \mathrm{mg}$ $\mathrm{C} \mathrm{m} \mathrm{m}^{-3} \mathrm{~d}^{-1}$ and Stn 73: $\left.12.6 \pm 0.25 \mathrm{mg} \mathrm{C} \mathrm{m}^{-3} \mathrm{~d}^{-1}\right)$. The lowest initial rates of $\mathrm{CO}_{2}$ fixation were measured at the two northern stations (Stn 101: $3.4 \pm 1.82 \mathrm{mg} \mathrm{C} \mathrm{m}^{-3} \mathrm{~d}^{-1}$ and Stn.128: $\left.3.6 \pm 0.09 \mathrm{mg} \mathrm{C} \mathrm{m}^{-3} \mathrm{~d}^{-1}\right)$. No data were available for the Bering
Strait station (Stn. 8). Overall, the rate of $\mathrm{CO}_{2}$ fixation was highly correlated with sea surface temperature $\left(\mathrm{CO}_{2}\right.$ fixation rate vs. temp.: $\left.m=3.9 \mathrm{mg} \mathrm{C} \mathrm{m}{ }^{-3} \mathrm{~d}^{-1}{ }^{\circ} \mathrm{C}^{-1}, r=0.92, p<0.05\right)$, but was independent of nutrient concentration and MLD.

The initial rate of $\mathrm{NO}_{3}{ }^{-}$uptake was highest at the Bering Strait (Stn. 8, $1.0 \pm 0.16 \mathrm{mmol} \mathrm{NO}_{3}{ }^{-} \mathrm{m}^{-3} \mathrm{~d}^{-1}$, Table 1). At the two mid-shelf sites, $\mathrm{NO}_{3}{ }^{-}$uptake was variable, with the rate at Stn. 46 $\left(0.4 \pm 0.26 \mathrm{mmol} \mathrm{NO}_{3}{ }^{-} \mathrm{m}^{-3} \mathrm{~d}^{-1}\right)$ being 20 -fold higher than at Stn. $73\left(0.02 \pm 0.003 \mathrm{mmol} \mathrm{NO}_{3}{ }^{-} \mathrm{m}^{-3} \mathrm{~d}^{-1}\right)$. Similarly, the rate of $\mathrm{NO}_{3}{ }^{-}$uptake differed between the two most northern sites, where rates measured at Stn. $101\left(0.2 \pm 0.016 \mathrm{mmol} \mathrm{NO}_{3}{ }^{-} \mathrm{m}^{-3}\right.$ $\left.\mathrm{d}^{-1}\right)$ were 20-fold higher than at Stn. $128(0.01 \pm 0.002 \mathrm{mmol}$ $\mathrm{NO}_{3}^{-} \mathrm{m}^{-3} \mathrm{~d}^{-1}$ ). At the coastal ACC site (Stn. 152), rates were also low $\left(0.01 \pm 0.006 \mathrm{mmol} \mathrm{NO}_{3}{ }^{-} \mathrm{d}^{-1}\right)$. Similar to $\mathrm{CO}_{2}$ fixation rate, $\mathrm{NO}_{3}{ }^{-}$uptake rate was independent of nutrient concentrations or MLD, but was highly correlated with sea surface temperature $\left(\mathrm{NO}_{3}{ }^{-}\right.$uptake rate vs. temp.: $m=0.16 \mathrm{mmol}$ $\left.\mathrm{NO}_{3}{ }^{-} \mathrm{m}^{-3} \mathrm{~d}^{-1}{ }^{\circ} \mathrm{C}^{-1}, r=0.89, p<0.05\right)$.

Lastly, initial heterotrophic prokaryote abundance was highest at the Bering Strait site (Stn. 8: $2.2 \pm 0.20 \times 10^{8}$ cells $^{-3}$ ) and

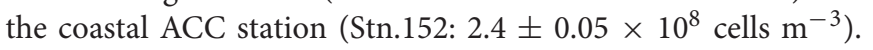
Only slightly lower abundances were measured at the two midshelf sites (Stn. 46: $1.9 \pm 0.06 \times 10^{8}$ cells $\mathrm{m}^{-3}$ and Stn. 73: $1.7 \pm 0.16 \times 10^{8}$ cells $\mathrm{m}^{-3}$ ) while the northern, shallower, station (Stn. 101) and the deeper northern site (Stn. 128) had the lowest abundance of heterotrophic prokaryotes $\left(0.6 \pm 0.01 \times 10^{8}\right.$ and $0.7 \pm 0.02 \times 10^{8}$ cells $\mathrm{m}^{-3}$, respectively). The $\% \mathrm{HNA}$ of the community ranged from 30.6 to $79.5 \%$ (Table 1 ) but showed no relationship to heterotrophic prokaryote abundance $(r=0.40$, $p>0.05)$. Heterotrophic prokaryote production, on the other hand, was positively correlated with heterotrophic prokaryote abundance $(r=0.84, p<0.05)$. As such, the mid-shelf site (Stn. 101) and the coastal ACC station (Stn. 152) had the lowest heterotrophic prokaryote production rates while the highest rates ( $\sim 5$-fold higher) were measured at the Bering Strait and the other mid-shelf (Stn. 73) station (Table 1). Additionally, a weak relationship was observed between $\% \mathrm{HNA}$ and heterotrophic prokaryote production $\left(m=0.53 \%\left[\mu \mathrm{g} \mathrm{C} \mathrm{m}^{-3} \mathrm{~d}^{-1}\right]^{-1}, r=0.71\right.$, $p<0.05)$. While heterotrophic prokaryote abundance was weakly correlated to Chl $a$ concentrations $\left(m=1.02 \times 10^{8}\right.$ cells $\mathrm{m}^{-3}[\mathrm{mg}$ Chl $\left.\left.a \mathrm{~m}^{-3}\right]^{-1}, r=0.57, p<0.05\right)$, both BP and \%HNA were more strongly correlated with Chl $a$ (\%HNA vs. Chl $a$ : $m=35.74 \%[\mathrm{mg}$ Chl $\left.a \mathrm{~m}^{-3}\right]^{-1}, r=0.77, p<0.05$; BP vs. Chl $a: m=44.37 \mu \mathrm{g} \mathrm{C}$ $\left.\mathrm{m}^{-3} \mathrm{~d}^{-1}\left[\mathrm{mg} \mathrm{Chl} a \mathrm{~m}^{-3}\right]^{-1}, r=0.72, p<0.05\right)$.

\section{Treatment Responses Nutrients}

Consumption of $\mathrm{NO}_{3}{ }^{-}$in the control treatment at the two sites with detectable $\mathrm{NO}_{3}{ }^{-}$in the sampled waters (Stns. 8 and 128) was complete during the incubations (Figures 2A,E). At all other sites, initial $\mathrm{NO}_{3}{ }^{-}$concentrations were undetectable and remained so for the entirety of the experiments. $\mathrm{NO}_{3}{ }^{-}$ was consumed in the treated bottles of most of the experiments (Figures 2A-F). The greatest consumption was at the Bering Strait site (Stn. 8) where close to $7.0 \mathrm{mmol} \mathrm{m}^{-3}$ was taken up during the $96 \mathrm{~h}$ experiment. Consumption of $\mathrm{NO}_{3}{ }^{-}$at the mid-shelf site (Stn. 73) was $\sim 5 \mathrm{mmol} \mathrm{m}^{-3}$, while at the other 


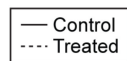

A
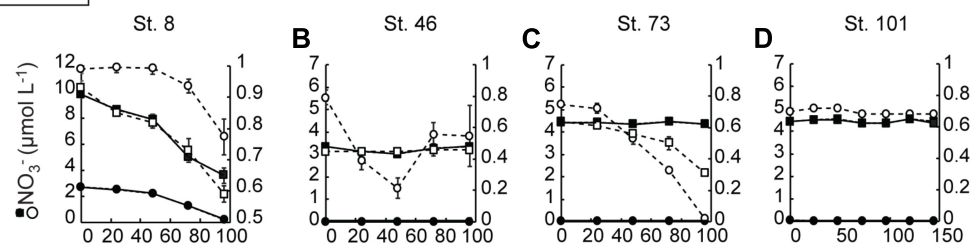

G
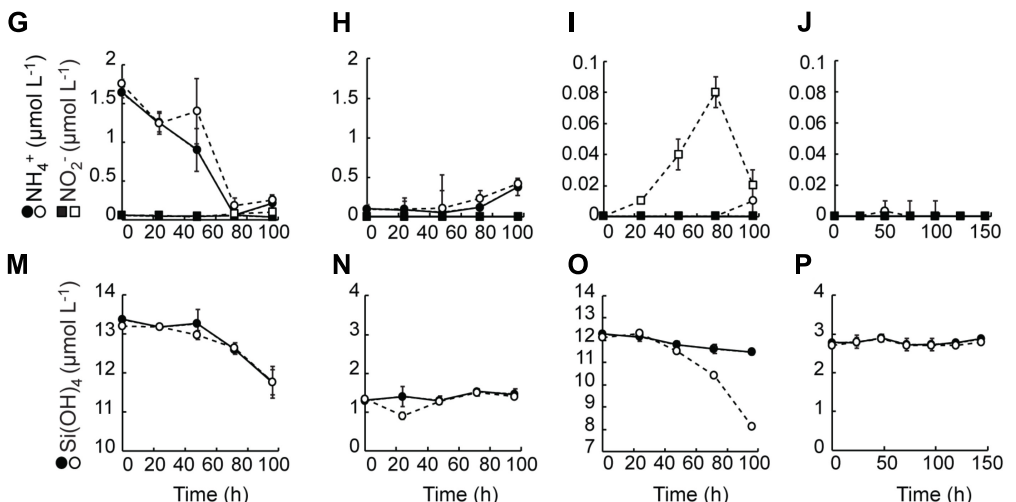
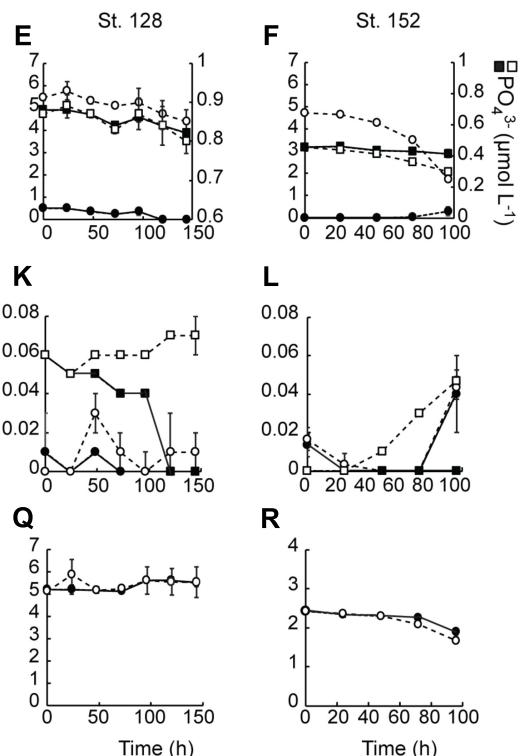

$\mathbf{R}$

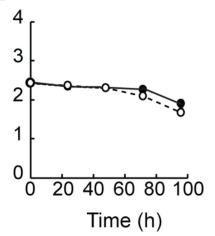

FIGURE 2 | Average $( \pm S D)$ nutrient concentrations measured during the nutrient amendment experiments. Solid lines are control and dashed lines are treated bottles. $\mathrm{NO}_{3}{ }^{-}$and $\mathrm{PO}_{4}{ }^{3-}(\mathbf{A}-\mathbf{F}), \mathrm{NH}_{4}$ and $\mathrm{NO}_{2}{ }^{-}(\mathbf{G}-\mathbf{L}), \mathrm{Si}(\mathrm{OH})_{4} \mathbf{( M - R}$.

mid-shelf site (Stn. 46) $\mathrm{NO}_{3}{ }^{-}$consumption was $\sim 1.75 \mathrm{mmol}$ $\mathrm{m}^{-3}$. Likewise, $\mathrm{NO}_{3}{ }^{-}$was taken up in the treated bottles at the coastal shelf site (Stn. 152, $\sim 1 \mathrm{mmol} \mathrm{m}^{-3}$ ) and at the deeply sampled off-shelf site (Stn. 128, $\sim 3 \mathrm{mmol} \mathrm{m}^{-3}$ ). At only the shallow off-shelf site (Stn. 101) there was an insignificant amount of $\mathrm{NO}_{3}{ }^{-}$consumed in the treated bottles during the experiment.

$\mathrm{PO}_{4}{ }^{3-}$ was consumed more in the $+\mathrm{NO}_{3}{ }^{-}$treatments than in the controls in three of the six experiments (Stns. 8, 73, 152) (Figures 2A-F). The greatest difference between treated and controls was at the mid-shelf site (Stn. 73), where close to $0.3 \mathrm{mmol} \mathrm{PO}_{4}{ }^{3-} \mathrm{m}^{-3}$ was consumed in waters with added $\mathrm{NO}_{3}{ }^{-}$, relative to no $\mathrm{PO}_{4}{ }^{3-}$ uptake in the control. At Stns. 8 and 128, the differences in $\mathrm{PO}_{4}{ }^{3-}$ consumption between the control and treated bottles was $<0.15 \mathrm{mmol} \mathrm{m}^{-3}$. At the more deeply sampled off-shelf site, which had initially detectable $\mathrm{NO}_{3}{ }^{-}$concentrations, approximately $0.05 \mathrm{mmol} \mathrm{PO}_{4}{ }^{3-} \mathrm{m}^{-3}$ was consumed in both the control and treatment, while at the shallowly sampled off-shelf site, no $\mathrm{PO}_{4}{ }^{3-}$ uptake was detected during the incubation. Likewise, at the mid-shelf site (Stn. 46) no $\mathrm{PO}_{3}{ }^{-}$uptake was recorded in either the control or the $\mathrm{NO}_{3}{ }^{-}$ treated bottles.

$\mathrm{NH}_{4}{ }^{+}$concentrations were only initially detectable $\left(\sim 1.65 \mathrm{mmol} \mathrm{m}^{-3}\right)$ at the Bering Strait site (Stn. 8) and were depleted at the same rate in both the control and $+\mathrm{NO}_{3}{ }^{-}$treatments by the $T=72 \mathrm{~h}$ sampling (Figures 2G-L). Concentrations then rose to $\sim 0.25 \mathrm{mmol} \mathrm{m}^{-3}$ in both treatments at the final $T=96 \mathrm{~h}$ time point. The only other site with detectable $T=0 \mathrm{NH}_{4}{ }^{+}$concentrations was the mid-shelf site (Stn. 46) where concentrations were $\leq 0.1 \mathrm{mmol} \mathrm{m}^{-3}$. These $\mathrm{NH}_{4}{ }^{+}$ concentrations remained low until the final $48 \mathrm{~h}$ in both treatments when they started to increase. $\mathrm{NH}_{4}{ }^{+}$concentrations remained below detection $\left(0.02 \mathrm{mmol} \mathrm{m}^{-3}\right)$ in both treatments at the other mid-shelf site (Stn. 73) and at the shallowly sampled off-shelf site (Stn. 101). At the more deeply sampled off-shelf site (Stn. 128), $\mathrm{NH}_{4}{ }^{+}$was only detectable at the $T=48 \mathrm{~h}$ time point in the $+\mathrm{NO}_{3}{ }^{-}$treatment, while at the coastal site (Stn. 152) $\mathrm{NH}_{4}{ }^{+}$concentrations rose to detectable levels $(\sim 0.04 \mathrm{mmol}$ $\mathrm{m}^{-3}$ ) in both the control and $\mathrm{NO}_{3}{ }^{-}$treated bottles.

Concentrations of $\mathrm{NO}_{2}{ }^{-}$were only initially detectable at the Bering Strait site (Stn. 8) and the deeply sampled off-shelf site (Stn. 128) (Figures 2G-L). The $\mathrm{NO}_{2}{ }^{-}$concentrations were depleted in the control treatment during all experiments at these sites. At all other sites, $\mathrm{NO}_{2}{ }^{-}$remained undetectable in the controls throughout the experiments. At multiple sites, however, $\mathrm{NO}_{2}{ }^{-}$concentrations increased in the $+\mathrm{NO}_{3}{ }^{-}$treatment during the incubations. For example, at the Bering Strait site (Stn. 8), the $\mathrm{NO}_{2}{ }^{-}$concentrations were $0.04 \mathrm{mmol} \mathrm{m}{ }^{-3}$ higher at the end of the experiment (Figure 2G). Likewise, $\mathrm{NO}_{2}{ }^{-}$ concentrations rose 0.08 and $0.03 \mathrm{mmol} \mathrm{m}^{-3}$ at the mid-shelf (Stn. 73) and coastal sites (Stn. 152), respectively (Figures 2I,L). No significant increases in $\mathrm{NO}_{2}{ }^{-}$concentrations were recorded in the treated bottles at the shallowly sampled off-shelf site (Stn. 101) (Figure 2J), and they remained below detection $(0.03 \mu \mathrm{mol}$ $\mathrm{L}^{-1}$ ) at the deeply sampled off-shelf site (Stn. 128) (Figure 2K).

Finally, $\mathrm{Si}(\mathrm{OH})_{4}$ was detectable at the start of all the experiments (Figures 2M-R). At only three sites (Stn. 8, Stn. 73, and Stn. 152) did concentrations decrease over the course of the experiments. There was no treatment effect at the Bering Strait site (Stn. 8) (Figure 8M), while consumption of $\mathrm{Si}(\mathrm{OH})_{4}$ was stimulated in the $\mathrm{NO}_{3}{ }^{-}$treated bottles relative to the control at the mid-shelf (Stn. 73) (Figure 2O) and coastal (Stn. 152) sites (Figure 2R). At Stn. 73, $\sim 4 \mathrm{mmol} \mathrm{Si}(\mathrm{OH})_{4} \mathrm{~m}^{-3}$ was consumed 
in the $+\mathrm{NO}_{3}{ }^{-}$treatment while only $0.8 \mathrm{mmol} \mathrm{Si}(\mathrm{OH})_{4} \mathrm{~m}^{-3}$ was consumed in the control. This difference was less at the coastal site [Stn. 152, Control: $0.5 \mathrm{mmol} \mathrm{Si}(\mathrm{OH})_{4} \mathrm{~m}^{-3},+\mathrm{NO}_{3}{ }^{-}$ treatment: $0.8 \mathrm{mmol} \mathrm{Si}(\mathrm{OH})_{4} \mathrm{~m}^{-3}$ ].

\section{Pigments and Biomass}

$\mathrm{NO}_{3}{ }^{-}$addition resulted in $\mathrm{Chl} a$ concentrations that were 1.4 - 6.8-fold above the control at all sites except the mid-shelf sites (Stn. 46) (Figures 3A-F). The difference between control and treatment $\mathrm{Chl} a$ concentrations was lowest at the two sites with initially detectable levels of $\mathrm{NO}_{3}{ }^{-}$ (Stn. 8. treatment:control accumulation ratio $=1.4$, Stn. 128 treatment:control accumulation ratio $=1.8$ ) (Figures $3 \mathrm{~A}, \mathrm{E})$. At those sites where $\mathrm{NO}_{3}{ }^{-}$was not detected in the sampled water, the treatment:control $\mathrm{Chl} a$ accumulation ratios were much higher (4.6 - 6.8) (Figures 3C,D,F).

The abundance of phytoplankton cells $<10 \mu \mathrm{m}$ responded similarly to the addition of $\mathrm{NO}_{3}{ }^{-}$as did Chl $a$ concentrations, with two exceptions (Figures 3G-L). First, there was no significant treatment difference in the abundance of the $<10 \mu \mathrm{m}$ phytoplankton in the Bering Strait experiment (Stn. 8), with both the control and $\mathrm{NO}_{3}{ }^{-}$treatments showing similar increases.
Secondly, a treatment difference in $<10 \mu \mathrm{m}$ phytoplankton cell abundance was detected at the mid-shelf site Stn. 46 with the $\mathrm{NO}_{3}{ }^{-}$treatment having $\sim 2$-fold higher abundance than the control (which showed no increase) at the final time point $(T=96 \mathrm{~h})$. This was in contrast to the Stn $46 \mathrm{Chl} a$ response which showed no increase in either the control or $\mathrm{NO}_{3}{ }^{-}$treatments (Figure 3B). At all other sites, the final abundance of the $<10 \mu \mathrm{m}$ phytoplankton cells was higher (1.5-3.6-fold) in the $+\mathrm{NO}_{3}{ }^{-}$treatment than in the control. It should be noted that in those experiments with no initially detectable $\mathrm{NO}_{3}{ }^{-}$, the final abundance of the $<10 \mu \mathrm{m}$ phytoplankton cells in the control was not significantly different from the start, while at the Bering Strait and deeply sampled off-shelf site, increases were observed in both the control and $\mathrm{NO}_{3}{ }^{-}$treatments (Figures 3G,K). Additionally, in all experiments, except for the shallowly sampled off-shelf station (St. 101), the $\mathrm{C}$ concentration of the $>8 \mu \mathrm{m}$ class increased in response to the addition of $\mathrm{NO}_{3}{ }^{-}$(Figures $4 \mathrm{~A}-\mathrm{L}$ ).

Concentrations of POC and PON also tracked the changes observed in Chl $a$ concentrations, with relatively greater increases observed in the $\mathrm{NO}_{3}{ }^{-}$-amended waters (Figures 3M-X). Notable exceptions were again observed in the experiments at the Bering Strait (Stn. 8) and the first mid-shelf site (Stn. 46). At the former

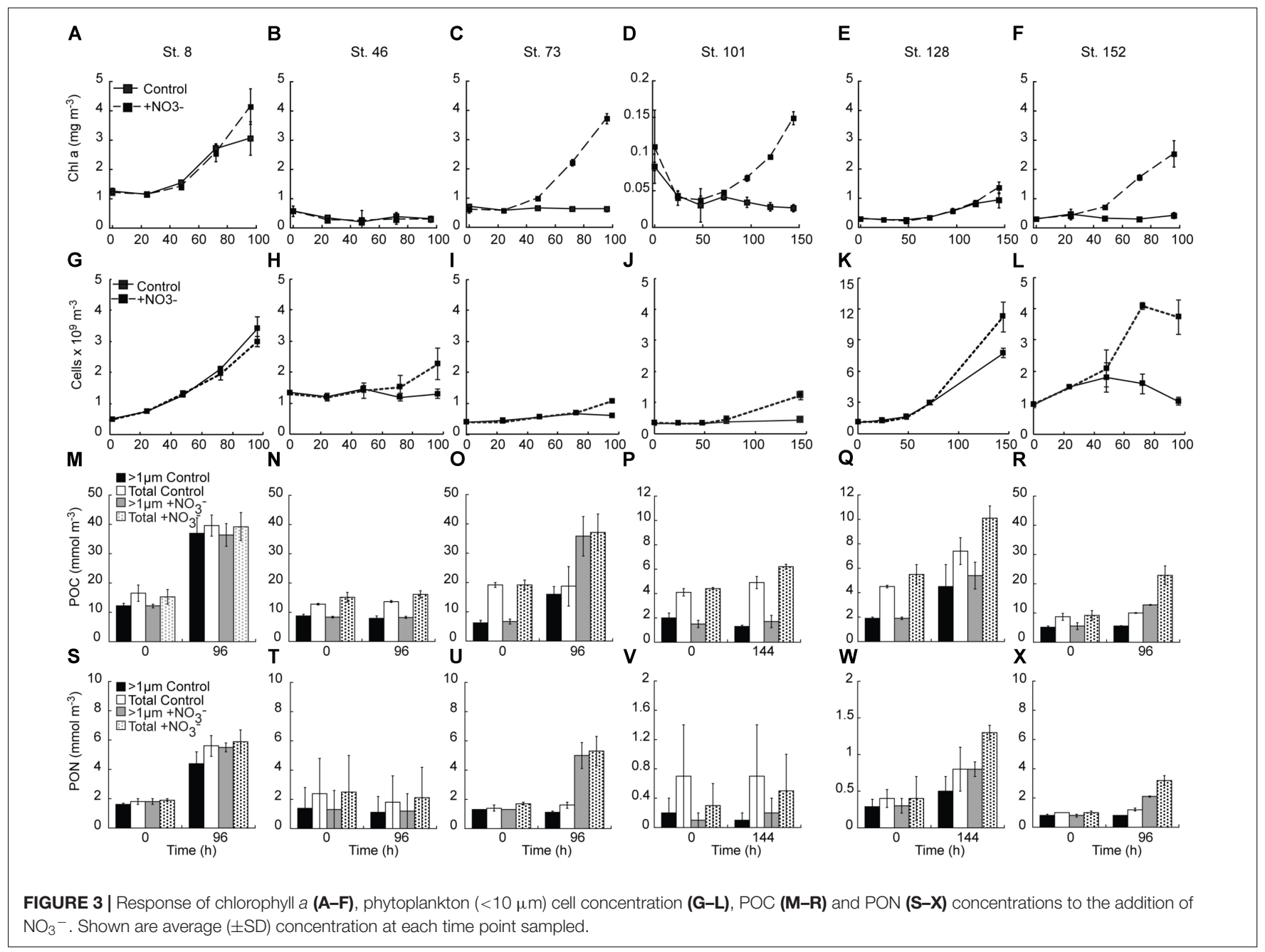




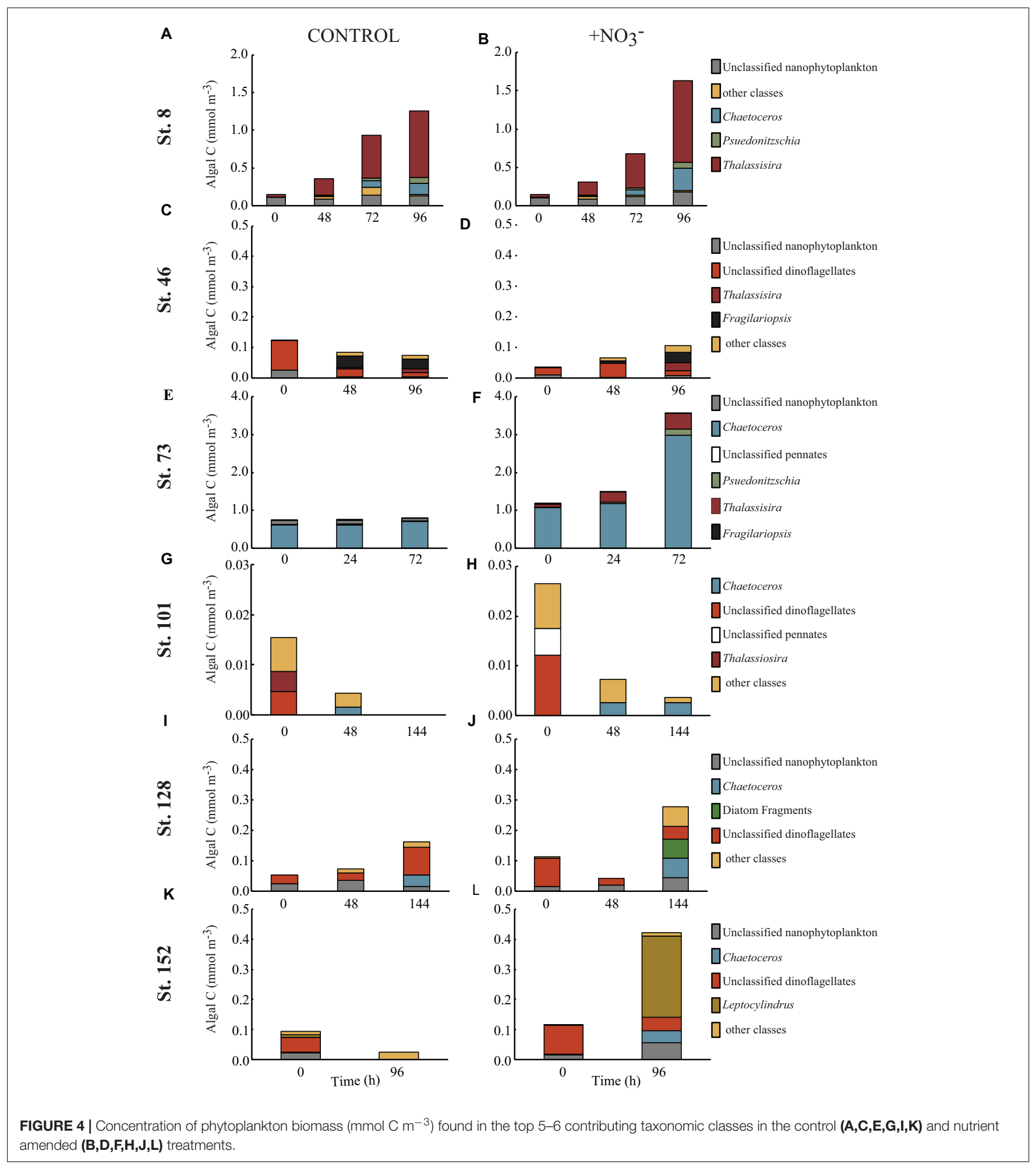

site, both the control and treated waters increased two-threefold in POC and PON while at the latter site POC and PON remained unchanged in both the control and treated bottles. At the remaining sites, relatively greater increases in both POC and PON were detected where $\mathrm{NO}_{3}{ }^{-}$was added, although little difference in PON was detected at the shallowly sampled off-shelf site (Stn. 101) (Figure 3V) because of high variability due to sample mass being close to detection limits.

The POC and PON responses by the two size classes measured varied in the different experiments. At the second mid-shelf site 
(Stn. 73), the $>1 \mu \mathrm{m}$-sized POC comprised $\sim 33 \%$ of the total POC pool. At $T=$ final, this increased to 85 and $96 \%$ in the control and $+\mathrm{NO}_{3}{ }^{-}$treatments, respectively. $\mathrm{PON}$ of the $>1 \mu \mathrm{m}$ size class, on the other hand, made up $80-90 \%$ of the initial PON pool but was only $70 \%$ of the total pool in the control, and $94 \%$ of the total pool in the $\mathrm{NO}_{3}{ }^{-}$-amended bottles, at $T=$ final. The two off-shelf sites differed from one another in that the primary particulate organic response at the shallowly sampled site was dominated by the $<1 \mu \mathrm{m}$ size fraction (i.e., while the total POC concentration increased, the $>1 \mu \mathrm{m}$ fraction remained constant) (Figure 3P). At the more deeply sampled off-shelf site (Stn. 128), this was not the case; the $>1 \mu \mathrm{m}$ sized POC increased from 30-40 to $50-60 \%$ of the total POC pool between the start and end of the incubation (Figure 3Q). Thus, while the $<1 \mu \mathrm{m}$ fraction was a significant component of the initial POC pool, accumulation of POC during the incubation was dominated by the $>1 \mu \mathrm{m}$ fraction. This was similar for PON at this station as well. Finally, there was no change in the amount of POC, or relative fraction of the $>1 \mu \mathrm{m}$ component in the control at the coastal site (Stn. 152). However, POC was stimulated by the addition of $\mathrm{NO}_{3}{ }^{-}$at this site, although the relative fraction of $\mathrm{POC}>1 \mu \mathrm{m}$ remained unchanged at $60 \%$ over the course of the experiment (Figure 3R). The PON response at this site differed with the fraction of total PON in the $>1 \mu \mathrm{m}$ size class, dropping from $\sim 73$ to $63 \%$ in both the control and $\mathrm{NO}_{3}{ }^{-}$treatments during the experiment (Figure 3X).

\section{Composition of the POC Pool}

The $>8 \mu \mathrm{m}$ phytoplankton size fraction decreased $86 \%$ at the shallowly sampled off-shelf site (Figure $4 \mathbf{H}$ ). At all other sites, the POC concentration of the $>8 \mu \mathrm{m}$ phytoplankton size class increased where $\mathrm{NO}_{3}{ }^{-}$was available, primarily due to diatom growth (Figures 4B,D,F,J,L). The diatom Thalassiosira was dominant, responding in the experiments at the Bering Strait site (Stn. 8) and the second mid-shelf site (Stn.73) (Figures 4B,E), while at the first mid-shelf site (Stn. 42) diatoms (e.g., Thalassiosira and Fragilariopsis) combined for $\sim 60 \%$ of the $\mathrm{C}$ increase in the $>8 \mu \mathrm{m}$ phytoplankton size class (Figure 4D). At the deeply sampled off-shelf site (Stn. 128), a mix of diatoms, nanoflagellates, and "other classes" all increased, while dinoflagellates decreased (Figure 4J). At the coastal site (Stn. 152) diatoms dominated the increase, primarily Leptocylindrus which increased $\sim 200 \%$, from $<0.01$ to $0.27 \mathrm{mmol} \mathrm{C} \mathrm{m}^{-3}$ (Figure $4 \mathrm{~L}$ ).

However, phytoplankton did not comprise the largest fraction of the $>8 \mu \mathrm{m}$ particulate pool. At all sites, except for the mid-shelf sites (Stn. 46 and 73), detritus made up $>50 \%$ of the initial particulate C pool (Figures 5C,E). In the case of Stn. 46, the particulate pool was composed of a mix of detritus $(\sim 46 \%$ in $T=0$ control) and phytoplankton that could not be classified as either diatom, dinoflagellate, prymnesiophyte, or nanoflagellate (i.e., "other taxa") (53\%), while at Stn. 73, diatoms made up $85-88 \%$ of the initial particulate $C$ pool. Composition of the initial non-detrital $\mathrm{C}$ pool at the non-mid-shelf sites was a mix of different algal taxa. At the Bering Strait site (Stn. 8), nanoflagellates and diatoms dominated the algal portion of the particulate C pool while at the off-shelf shallow site (Stn. 101), the algal particulate pool was composed primarily of equal fractions (5-14\%) of diatoms and dinoflagellates (Figures 5G,H). At the more deeply sampled off-shelf site, nanoflagellates (5-15\%) and dinoflagellates (17-28\%) dominated the starting algal community (Figures 5I,J). Finally, at the coastal site, the algal fraction of the particulate $C$ pool was made up of diatoms (2-5\%), nanoflagellates (4-6\%), and dinoflagellates (15-26\%) (Figures 4K,L).

Across all experiments, diatoms were the phytoplankton taxonomic group that responded most to the addition of $\mathrm{NO}_{3}{ }^{-}$ (Figure 5). Changes in the relative abundance of diatoms ranged from 12 to $41 \%$ across all experiments, with the greatest relative increases being at the first mid-shelf site (Stn. 46, 41\%), the deeply sampled off-shelf site (Stn. 128, 37\%) and the coastal site (Stn. 152, 39\%) (Figures 5D,I,J). Diatoms in the control also became a relatively greater fraction of the phytoplankton community at several sites, although the changes were smaller $(\max =16 \%$ at Stn. 42).

\section{Active Fluorescence Measurements}

$F_{\mathrm{v}}: F_{\mathrm{m}}$ was variable with respect to treatment differences between experiments (Figures 6A-F). At three sites there was a clear increase in $F_{\mathrm{v}}: F_{\mathrm{m}}$ in the $\mathrm{NO}_{3}{ }^{-}$treated waters relative to the controls. At the second mid-shelf site (Stn. 73), the shallowly sampled off-shelf site (Stn. 101), and the coastal site (Stn. 152), $F_{\mathrm{V}}: F_{\mathrm{m}}$ was 1.3-, 1.7-, and 1.1-fold higher in the $+\mathrm{NO}_{3}{ }^{-}$treatment than in the control at $T=$ final (Figures 6C,D,F). At the Bering Strait site, $F_{\mathrm{v}}: F_{\mathrm{m}}$ was higher at $T=$ final relative to the initial, although the response in the control and $\mathrm{NO}_{3}{ }^{-}$treated waters was the same (Figure 6A). In contrast to these four sites, the $+\mathrm{NO}_{3}{ }^{-}$treatment had a lower $F_{\mathrm{V}}: F_{\mathrm{m}}$ relative to the control at some point during the incubation (Figures $4 \mathrm{~B}, \mathrm{E}$ ) at the first mid-shelf site (Stn. 46) and the deeply sampled off-shelf site (Stn. 128), although the control and $\mathrm{NO}_{3}{ }^{-}$treated waters were the same at $T=$ final. At both these sites, $F_{\mathrm{v}}: F_{\mathrm{m}}$ was depressed at $T=$ final relative to initial values, while the reverse was true (i.e., it was stimulated) at Stns. 8, 73, 101, and 152 in the $\mathrm{NO}_{3}{ }^{-}$treated bottles.

There was no clear trend across experiments in the response of

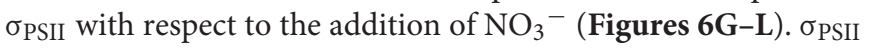
decreased in both the control and treated bottles at the Bering Strait site (Stn. 8), both mid-shelf sites (Stn. 46 and 73), and the deeply sampled off-shelf site (Stn. 128). The decrease ranged from 6 to $30 \%$ of initial values, and was greater in the control than the $+\mathrm{NO}_{3}{ }^{-}$treatment at Stns. 46 and 128. In contrast, a greater $\sigma_{\text {PSII }}$ decrease was observed in the control at Stn. 73 while no treatment difference was observed at the Bering Strait site (Stn. 8). At the shallowly sampled off-shelf site (Stn. 101), бPSI increased $10 \%$ relative to initial values whereas the control showed little difference at $T=$ final (Figure 6J). There was little to no treatment effect in $\sigma_{\text {PSII }}$ over the incubation period at the coastal site (Stn. 152) (Figure 6R).

Lastly, $1 / \tau_{\mathrm{Qa}}$ was generally higher in the $+\mathrm{NO}_{3}{ }^{-}$treatments relative to the control at all sites during the incubation period (Figures 6M-R), except for the coastal station (Stn. 152) (Figure 6R). The difference was greatest at the off-shelf sites where $1 / \tau_{\mathrm{Qa}}$ in the $+\mathrm{NO}_{3}{ }^{-}$treatment was 34 and $52 \%$ higher than the control at Stn. 101 and 128, respectively. At the two 


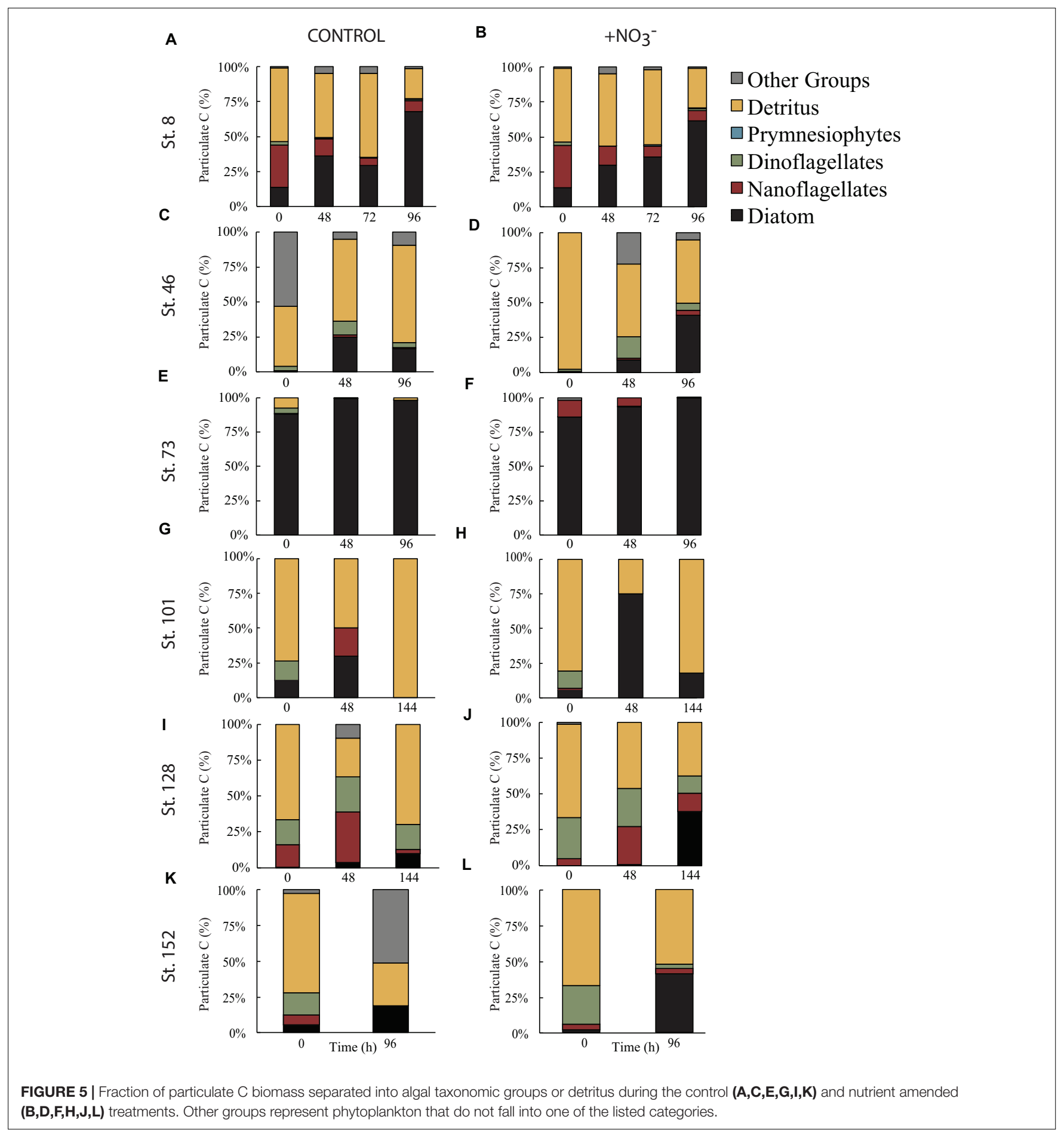

mid-shelf sites and the Bering Strait site, the $+\mathrm{NO}_{3}{ }^{-}$treatment increased $12-23$ and $5 \%$, respectively.

\section{$\mathrm{CO}_{2}$ Fixation and $\mathrm{NO}_{3}-$ Uptake Rates}

$\mathrm{CO}_{2}$ fixation rates were stimulated 1.3-8.0-fold above the initial rates in the $+\mathrm{NO}_{3}$ treatment in all experiments, and significantly above the control treatment (2.1-14.3-fold) in all experiments except at Stn. 8 (Bering Strait) and Stn. 73 (mid-shelf station)
(Figures 7A-F). The greatest increase in stimulation relative to the control was at the shallowly sampled off-shelf (Stn. 101) and coastal sites (Stn. 152) where the treated waters were $\sim 13-14$-fold higher than the controls. $\mathrm{NO}_{3}{ }^{-}$stimulated $\mathrm{CO}_{2}$ fixation rates above the controls at one of the mid-shelf sites (Stn. 46) and at the deeply sampled off-shelf site (Stn. 128), although the increases were less than above, exhibiting 2.2- and 3.3-fold higher rates, respectively. 

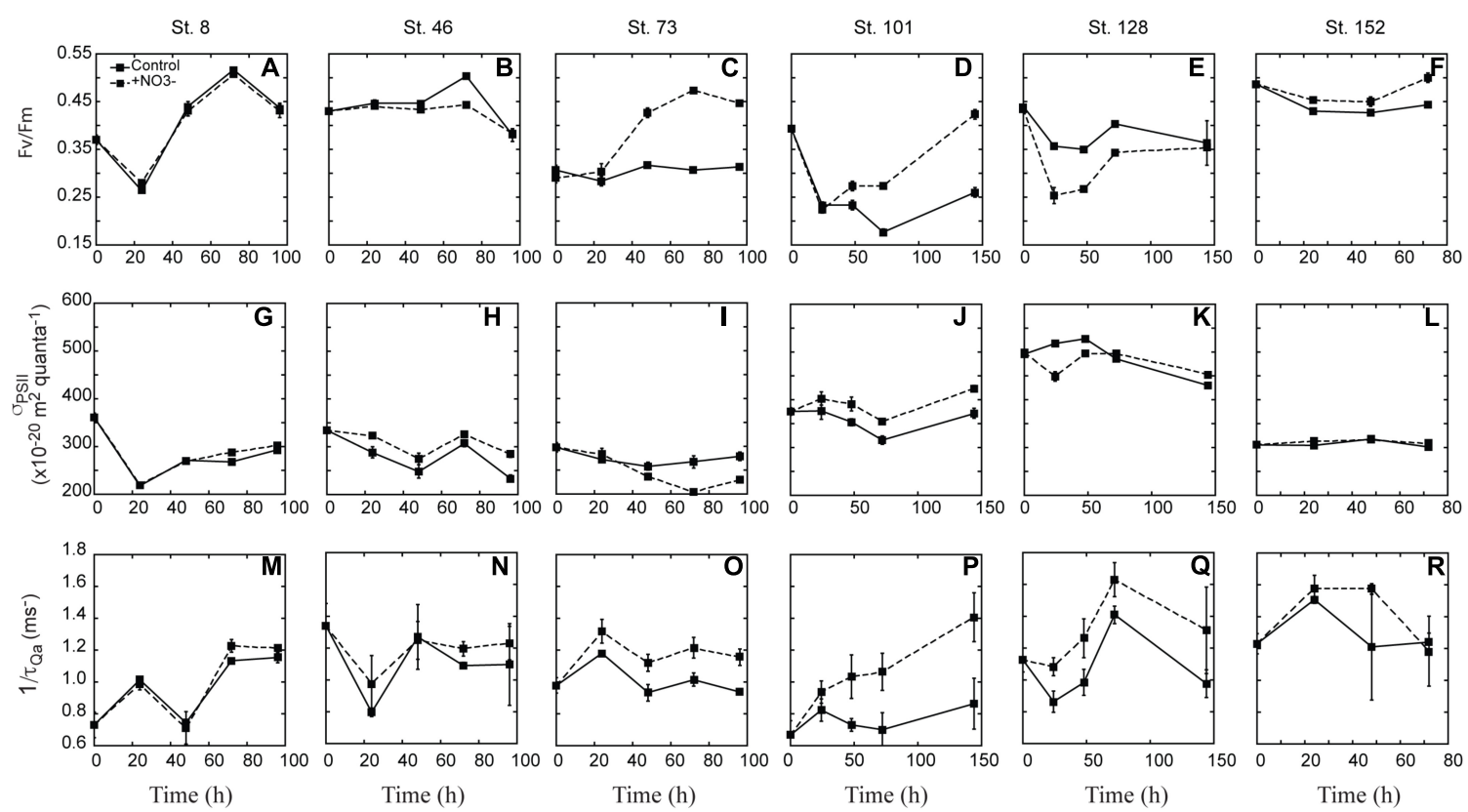

FIGURE 6 | Response of FRRf parameters $\left[F_{\mathrm{v}}: F_{\mathrm{m}}(\mathbf{A}-\mathbf{F}), \sigma_{\mathrm{PS}}(\mathbf{G}-\mathbf{L}), 1 / \tau_{\mathrm{QA}}(\mathbf{M}-\mathbf{R})\right]$ to the addition of $\mathrm{NO}_{3}{ }^{-}$. Shown are averages $( \pm \mathrm{SD})$ at each time point sampled.

$\mathrm{NO}_{3}{ }^{-}$uptake rates were stimulated relative to initial rates in the $+\mathrm{NO}_{3}{ }^{-}$treatments in all the experiments except at the mid-shelf station 46 (Figures 7G-L). However, the addition of $\mathrm{NO}_{3}{ }^{-}$stimulated uptake relative to the control at only three of those five stations $\left(73,128\right.$, and 152). In these experiments, $\mathrm{NO}_{3}{ }^{-}$ uptake rates were $14-78$-fold higher in the $+\mathrm{NO}_{3}{ }^{-}$treatment than in the controls (Figures $7 \mathbf{I}, \mathbf{K}, \mathbf{L}$ ). $\mathrm{NO}_{3}{ }^{-}$uptake rates were usually highest in the $>1 \mu \mathrm{m}$ size fraction (Figures $7 \mathbf{M}-\mathbf{R}$ ), although uptake by $<1 \mu \mathrm{m}$ cells was still significant in several experiments. For example, the $<1 \mu \mathrm{m}$ sized cells accounted for $\sim 40-90 \%$ of $\mathrm{NO}_{3}{ }^{-}$uptake at the mid-shelf Stn. 46 (Figure $7 \mathrm{~N}$ ).
Additionally, at the shallow off-shelf site (Stn. 101), the $<1 \mu \mathrm{m}$ sized cells accounted for $>90 \%$ of measured $\mathrm{NO}_{3}{ }^{-}$uptake rates in the control treatment, but only $25 \%$ in the $+\mathrm{NO}_{3}{ }^{-}$treatment (Figure 7P). The reverse was true at the coastal site (Stn. 152) where $\mathrm{NO}_{3}{ }^{-}$uptake in the $<1 \mu \mathrm{m}$ size fraction was undetectable in the control but accounted for $\sim 50 \%$ of the measured rate in the $+\mathrm{NO}_{3}{ }^{-}$treatment (Figure $7 \mathbf{R}$ ).

\section{Heterotrophic Prokaryote Abundance and Production} There was little treatment difference with respect to abundance of heterotrophic prokaryotes across all experiments

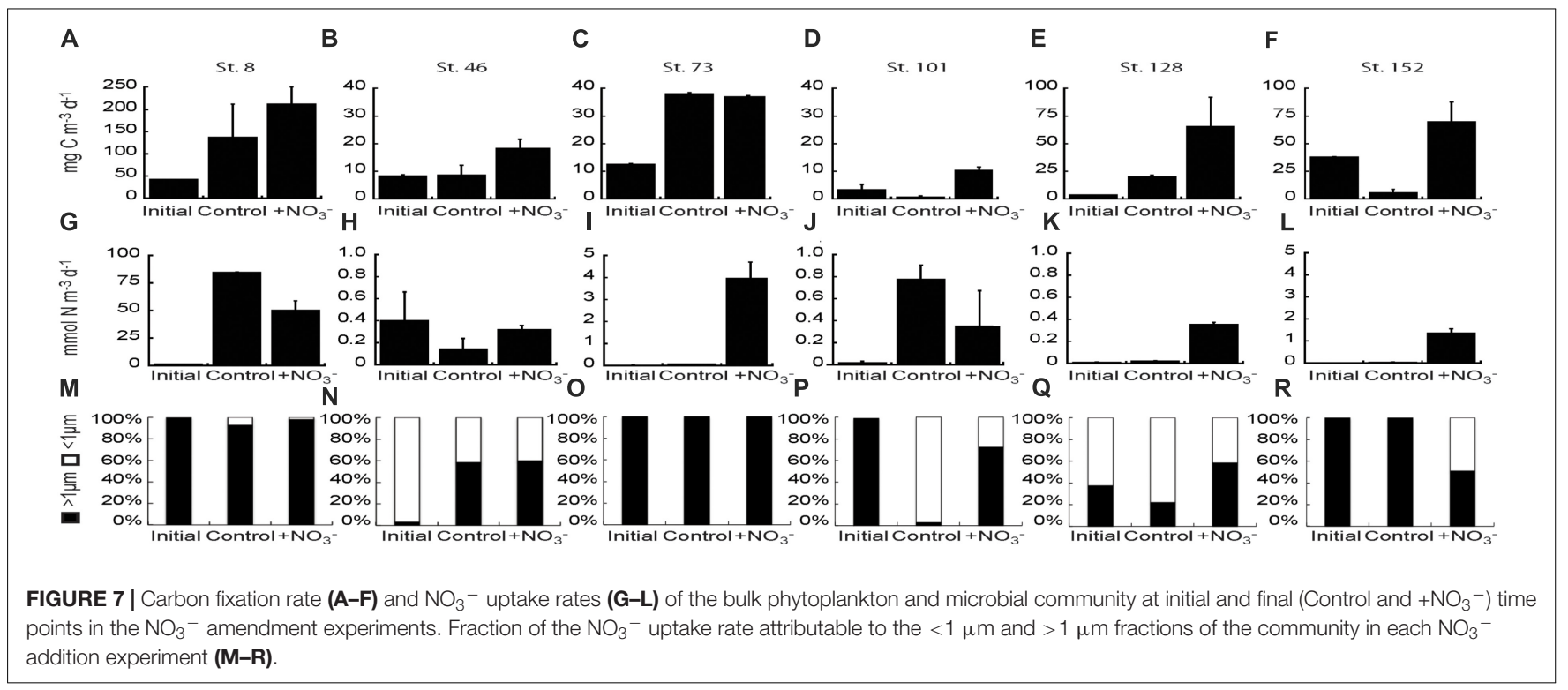


(Figures 8A-F). Only the two mid-shelf sites (Stn. 46 and 73) showed a higher abundance ( $\sim 12$ and $26 \%$, respectively) of heterotrophic prokaryotes where $\mathrm{NO}_{3}{ }^{-}$was added (Figures 8B,C). Despite changes in heterotrophic prokaryote production during the experiments, within treatment variability was high and virtually no treatment differences were detected (Figures 8G-L). Only at the shallowly sampled off-shelf site (Stn. 101) was a treatment difference in heterotrophic prokaryote production rate detected, with the $+\mathrm{NO}_{3}{ }^{-}$treatment having a 4.8-fold higher rate than the control at $T=$ final (Figure 8J). Finally, while changes in the percent of the heterotrophic prokaryote community composed of HNA-containing cells changed in the different experiments (e.g., increased $20-50 \%$ in 4 of the 6 experiments), no effect of the added $\mathrm{NO}_{3}{ }^{-}$was detected (Figures 8M-R).

\section{Summary}

The relative responses of different variables in the treatments compared to the controls can be used to determine how similarly the different experiments responded to the $+\mathrm{NO}_{3}{ }^{-}$additions (Figure 9). For example, across all experiments, consumption of $\mathrm{PO}_{4}{ }^{3-}$ was greater in the $\mathrm{NO}_{3}{ }^{-}$treatment than in the control by the final time point. The same was not true for $\mathrm{Si}(\mathrm{OH})_{4}$, where only three of the experiments (Stns. 73,128 , and 152) responded to the $\mathrm{NO}_{3}{ }^{-}$addition with increased $\mathrm{Si}(\mathrm{OH})_{4}$ consumption. Likewise, total POC concentrations increased in the treated waters, relative to the controls, at all sites except the Bering Strait site (Stn. 8). Overall, the cumulative response to $\mathrm{NO}_{3}{ }^{-}$additions was similar between Stns. 73 and 152. These two stations showed relatively greater nutrient consumption, phytoplankton biomass, particulate nutrient concentrations, and $\mathrm{NO}_{3}{ }^{-}$uptake rates in the treated waters than in the control. Of the remaining stations, which clustered together despite some differences, the response to $\mathrm{NO}_{3}{ }^{-}$was most similar between Stn. 46 and 128. Both had relatively similar responses in POC and PON concentrations, $\mathrm{CO}_{2}$ fixation, $\mathrm{NO}_{3}{ }^{-}$uptake, heterotrophic prokaryote production rates, and $1 / \tau_{\mathrm{QA}} \mathrm{Stn} .8$ was the next most similar to these stations, while the response at Stn. 101 was the most different from any of the stations in this second cluster. Despite the differences between the stations, the overall biological response across all experiments suggested that $\mathrm{NO}_{3}{ }^{-}$resulted in greater consumption of $\mathrm{PO}_{4}{ }^{3-}$ and increases in phytoplankton cell abundance $(<10 \mu \mathrm{m}), \mathrm{POC}$ and $\mathrm{PON}, \mathrm{CO}_{2}$ fixation, $\mathrm{NO}_{3}{ }^{-}$ uptake, and $F_{\mathrm{v}} / F_{\mathrm{m}}$, but a decrease in $1 / \tau_{\mathrm{QA}}$.

\section{DISCUSSION}

\section{Phytoplankton Response to Added $\mathrm{NO}_{3}{ }^{-}$}

Our a priori hypothesis was that $\mathrm{N}$ availability was the primary factor limiting phytoplankton productivity in the Chukchi Sea during the summertime. Apart from the Bering Strait, the surface waters of the Chukchi Sea were depleted of DIN, and thus were consistent with this hypothesis. The three sites on the shelf (Stns. 46,73 , and 152) all had undetectable surface concentrations of $\mathrm{NO}_{3}{ }^{-}$and $\mathrm{NO}_{2}{ }^{-}$, while $\mathrm{NH}_{4}{ }^{+}$was detectable only at Stn. 46. Additionally, while $\mathrm{NO}_{3}{ }^{-}$was barely detectable at the shallowly sampled off-shelf site (Stn. 101), both $\mathrm{NO}_{2}{ }^{-}$and $\mathrm{NH}_{4}{ }^{+}$were also depleted. On the other hand, Stn. 128, which was sampled deeper, did have some available $\mathrm{NO}_{3}{ }^{-}$and $\mathrm{NO}_{2}{ }^{-}$. In contrast to DIN, $\mathrm{PO}_{4}{ }^{3-}$ and $\mathrm{Si}(\mathrm{OH})_{4}$ were detectable at all sites on and off the shelf.

The biological responses from the three shelf sites, and both off-shelf sites, suggested that the phytoplankton community

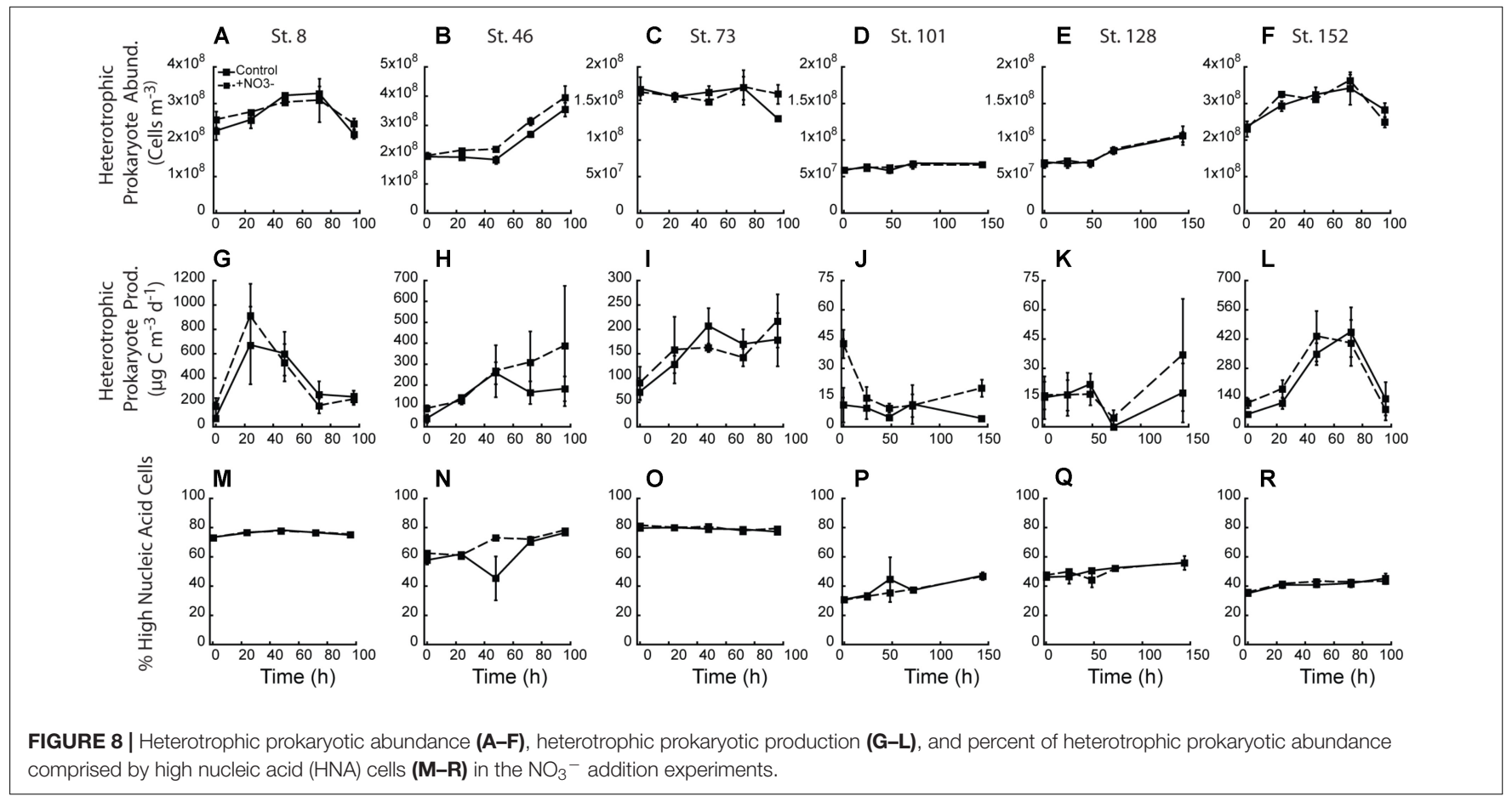




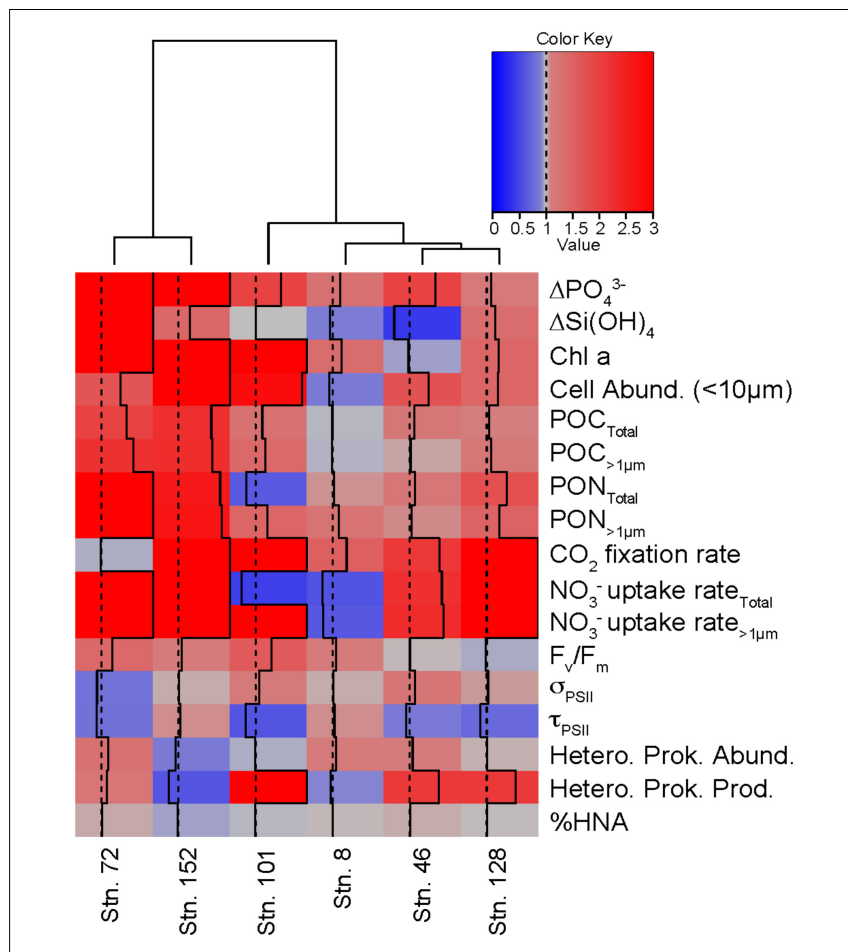

FIGURE 9 | Comparison of different experiments showing the relative response $\left(+\mathrm{NO}_{3}{ }^{-}\right.$: Control) for multiple variables in each experiment. Dotted line indicates value of 1 while solid line indicates the value of the responses. Values $\geq 3$ are indicated by solid line on the right edge of the box. Hierarchical clustering using Ward's minimum variance method was used to group experiments with similar relative responses.

was N-limited. Concentrations of $\mathrm{Chl} a, \mathrm{POC}, \mathrm{PON}$, and the proportion of phytoplankton $<10 \mu \mathrm{m}$ increased more in the $\mathrm{NO}_{3}{ }^{-}$-treated samples than in the controls. Likewise, $\mathrm{CO}_{2}$ fixation and $\mathrm{NO}_{3}{ }^{-}$uptake rates were higher in the $\mathrm{NO}_{3}{ }^{-}$-amended treatment at four of the six stations (not Stns. 8 and 46), especially where surface $\mathrm{N}$ was fully depleted. Across multiple experiments, diatom abundance increased in response to this $\mathrm{NO}_{3}^{-}$addition. However, the expected coincident decrease in $\mathrm{Si}(\mathrm{OH})_{4}$ concentrations due to this diatom growth was not always observed. Finally, while both the $F_{\mathrm{V}} / F_{\mathrm{m}}$ and $\sigma_{\text {PSII }}$ responses were variable, with only three of the six stations showing a similar response to $\mathrm{NO}_{3}{ }^{-}$(i.e., an increase), $1 / \tau_{\mathrm{QA}}$ was consistently higher in the $+\mathrm{NO}_{3}{ }^{-}$-treatment than in the control (discussed below). Together, these biological responses can be interpreted as direct confirmation of proximal N-limitation of the summertime Chukchi Sea phytoplankton community.

Previous work supports N-limited phytoplankton productivity in Arctic waters, with several studies indicating that $\mathrm{N}$ is the first nutrient depleted during the spring bloom. Tremblay and Gagnon (2009) reviewed multiple studies and found that the magnitude of the $\mathrm{N}$ inventory at the start of the phytoplankton growing season was the primary predictor of water column primary productivity, more so than light or temperature. They noted a positive relationship between phytoplankton productivity and depth and open water duration, suggesting that deeper waters have a larger reservoir of available $\mathrm{N}$ that can be mixed upward during storms and/or upwelling periods. The longer ice-free periods allow for a greater likelihood of mixing of nutrients into surface waters, and thus productivity in these waters is sustained by the vertical nutrient fluxes. Tremblay and Gagnon (2009) concluded that only external $\mathrm{N}$ inputs, such as river runoff rich in DON or atmospheric deposition, can increase phytoplankton productivity of shallow seas, like the Chukchi Sea, beyond what the start of the season $\mathrm{N}$ inventory provides.

Likewise, Yun et al. (2016) related primary production of the Chukchi Sea to nutrient availability. However, they indicated that increased freshwater content results in a decreased $\mathrm{NO}_{3}{ }^{-}$inventory, and consequently, decreased rates of primary production. In fact, they note a decreasing trend in primary production rates in the Chukchi Sea between 1974 and 2012, and suggest that this is the result of a $30-50 \%$ decrease in the Chukchi Sea nutrient inventory and associated 40\% decrease in depth-integrated Chl a concentration associated with the noted increase of freshwater to the Chukchi Sea (Serreze et al., 2006). Data from the ICESCAPE campaign do not support the conclusion of Yun et al. (2016) that primary productivity is decreasing in the Chukchi Sea. Lewis et al. (2018) show that productivity during our study period averaged $2.5 \pm 4.6 \mathrm{~g} \mathrm{C}$ $\mathrm{m}^{-2} \mathrm{~d}^{-1}$ over 39 stations in the Chukchi Sea, which was greater than in any of the studies cited by Yun et al. (2016). In fact, the highest numbers they cite (Hameedi, 1978) were collected in July, the same month as the ICESCAPE campaign. Generally, primary productivity is relatively high in June/July and decreases as nutrients are consumed during the summer season, such that by August/September nutrients are consumed and productivity is low. Satellite ocean color data confirm this seasonal cycle between July and September (Pabi et al., 2008). The multi-decadal decreasing trend noted by Yun et al. (2016) likely reflects the expected annual cycle of productivity and nutrient consumption over the shelf captured during field campaigns conducted over multiple years, with each sampling progressively later in the seasonal cycle. The Yun et al. (2016) conclusions directly contrast the continued increase of Chukchi Sea open water annual net primary production rates estimated by Arrigo and van Dijken (2015) using ocean color satellites, which was linked to greater open water areas and longer open water duration. If the greater open water area is associated with deeper regions of the shelf, the longer open water duration may provide greater opportunity for storms to result in mixing of deeper nutrient reservoirs that increase areal phytoplankton productivity rates (Pabi et al., 2008).

Additional evidence from the ICESCAPE field campaign supports the importance of $\mathrm{N}$ as the primary driver of phytoplankton productivity on the Chukchi Shelf during the summer. Enhanced phytoplankton biomass in the Chukchi Sea during both 2010 and 2011 was usually associated with WW (Lowry et al., 2015), defined as water with a potential temperature of $\leq-1.6^{\circ} \mathrm{C}$, but also containing high nutrient concentrations (Pickart et al., 2016). For example, during ICESCAPE, $\mathrm{NO}_{3}{ }^{-}$ concentrations on the Chukchi Shelf were $\sim 11$ times higher in WW than non-WW (Lowry et al., 2015). In regions on the 
shelf with WW, mean Chl $a$ concentrations were approximately threefold higher and POC concentrations were typically 30\% higher than regions not containing WW. Both $\mathrm{P}$ and $\mathrm{Si}$ are also available at higher concentrations in WW than non-WW, although the non-WW concentrations of these two elements are still relatively high compared to $\mathrm{NO}_{3}{ }^{-}$, which is undetectable in most places on the shelf during our sampling period (June-July). The co-location of elevated phytoplankton biomass and the main WW advective pathways during mid-June and July is further evidence that nutrients, especially $\mathrm{N}$, control summertime phytoplankton productivity in the Chukchi Sea.

\section{Winter Water Stations}

During the present study, we sampled only two stations that had WW bottom layers (Figure 1). At Stn. 46, WW was present only in the bottom $3 \mathrm{~m}$ of the $46 \mathrm{~m}$ water column while the surface water $(6 \mathrm{~m})$ had T-S characteristics similar to the ACC (Figure 1). In contrast, at Stn. 73, the WW layer was $20 \mathrm{~m}$ thick (bottom depth $39 \mathrm{~m}$ ) and was separated from the experimental sampling depth $(3 \mathrm{~m})$ by $16 \mathrm{~m}$. The mixed layer at Stn. 46 was slightly shallower $($ MLD $=12 \mathrm{~m})$ than at Stn. $73($ MLD $=14 \mathrm{~m})$, and the greater thickness of the WW bottom layer at Stn. 73 meant that the distance between the base of the mixed layer and the nutrient-rich WW was less at Stn. 73 than at Stn. 46, indicating that nutrients were more easily accessible.

These two sites exhibited significantly different responses to the addition of $\mathrm{NO}_{3}{ }^{-}$. While the concentration of phytoplankton $<10 \mu \mathrm{m}$ and the ${ }^{14} \mathrm{CO}_{2}$-fixation rates were all higher in the $+\mathrm{NO}_{3}{ }^{-}$treatment than in the controls at Stn. 46, the Chl $a$ concentration, $\mathrm{PO}_{4}{ }^{3-}$ and $\mathrm{Si}(\mathrm{OH})_{4}$ consumption, and $\mathrm{NO}_{3}{ }^{-}$ uptake rates all showed no stimulatory response. At Stn. 73, which had the greater volume of nutrient rich WW below the surface layer, greater biomass changes, $\mathrm{CO}_{2}$-fixation and $\mathrm{NO}_{3}-$ uptake rates were observed in the $\mathrm{NO}_{3}{ }^{-}$treatment relative to the control and initials. Likewise, $\mathrm{NO}_{3}{ }^{-}$uptake was dominated by the $>1 \mu \mathrm{m}$ size fraction, and the active fluorescence parameters all responded to the $\mathrm{NO}_{3}{ }^{-}$addition $\left(F_{\mathrm{V}} / F_{\mathrm{m}}\right.$ increased, $\sigma_{\text {PSII }}$ decreased, and $1 / \tau_{\mathrm{QA}}$ increased). The different responses between the two WW stations indicate that the phytoplankton community at Stn. 73 was primed and ready to use $\mathrm{NO}_{3}{ }^{-}$when it became available. We estimate that the diffusive flux of $\mathrm{NO}_{3}{ }^{-}$between the bottom of the mixed layer and the top of the WW to be $\sim 2.5$-fold greater at St. $73\left(0.7-4.8 \mu \mathrm{mol} \mathrm{m}^{-2} \mathrm{~d}^{-1}\right)$ than at St. 46 (0.3-1.9 $\left.\mu \mathrm{mol} \mathrm{m}{ }^{-2} \mathrm{~d}^{-1}\right)$. Likewise, while $\mathrm{PO}_{4}{ }^{3-}$ concentrations were similar at both sites, $\mathrm{Si}(\mathrm{OH})_{4}$ was lower at $\mathrm{Stn} .46(1.3 \mathrm{mmol}$ $\left.\mathrm{m}^{-3}\right)$ than at Stn. $73\left(12.2 \pm 0.12 \mathrm{mmol} \mathrm{m}^{-3}\right)$. Combined, the higher subsurface WW reservoir of $\mathrm{NO}_{3}{ }^{-}$and ambient $\mathrm{Si}(\mathrm{OH})_{4}$ concentrations at Stn. 73 suggest that a background population of diatoms was present and ready to grow once $\mathrm{NO}_{3}{ }^{-}$, the primary limiting nutrient, became available.

The composition of the initial phytoplankton communities at these two shelf sites is consistent with this hypothesis. Analysis using an IFCB determined that phytoplankton C biomass at Stn. 46 was dominated by unclassified dinoflagellates while at Stn. 73, the initial C biomass was dominated by the diatoms Chaetoceros sp. and Thalassiosira sp. (Figures $4 \mathrm{E}, \mathrm{F}$ ). It seems that while $\mathrm{N}$ was the element limiting the productivity of the phytoplankton across the Chukchi shelf, community composition at these two sites was controlled by the presence of available Si.

\section{Coastal vs. Off-Shelf Sites}

$\mathrm{N}$-limitation was also evident at the coastal shelf site in the nutrient depleted ACC (Stn. 152), as well as at the shallowly sampled off-shelf site (Stn. 101). While these two sites had similar initial nutrient concentrations, the physical environments were very different (Table $\mathbf{1}$ and Figure 1). Stn 101 was ice covered (86\%) and had less available light, had a sea surface temperature of $-1.03^{\circ} \mathrm{C}$, and a salinity of 28.6. In contrast, the ACC site had no sea ice cover, more light at the sampling depth, and was relatively warm $\left(7^{\circ} \mathrm{C}\right)$ and more saline (31.2). Despite these differences, the responses to nutrient additions were remarkably similar. Both sites responded to $+\mathrm{NO}_{3}{ }^{-}$with increases in $\mathrm{Chl} a$ concentration, phytoplankton cell abundance, $\mathrm{CO}_{2}$-fixation rate, $\mathrm{POC}$ concentration, and in the case of the ACC station, higher PON concentration. Additionally, $F_{\mathrm{v}}: F_{\mathrm{m}}$, $\sigma_{\mathrm{PSII}}$ (at Stn. 101), and $1 / \tau_{\mathrm{QA}}$ were all higher in the $+\mathrm{NO}_{3}-$ treatment relative to the control. Likewise, both experiments initially had significant numbers of unidentified dinoflagellates and phytoplankton $<10 \mu \mathrm{m}$ increased 6-11fold.

However, Stn. 101 was located on the edge of the Beaufort Gyre, which is considered permanently oligotrophic due to the accumulation of freshwater associated with sea ice melt and freshwater inputs at the coast, and is thus more stratified (McLaughlin and Carmack, 2010). In contrast, Stn. 152 was located in the ACC, which develops seasonally as warm nutrient-depleted water travels northward along the coast of Alaska from the Bering Strait. The similar bulk biological and biogeochemical responses between these two physically and chemically (in the case of salinity) different sites (Figure 1B and Table 1) supports the role of $\mathrm{N}$ availability ultimately controlling the growth and productivity of phytoplankton in the Chukchi Sea during our study period.

The data from these two sites suggest that during the summer in the Chukchi Sea, the low nutrient availability results in a phytoplankton community that is numerically dominated by small, occasionally non-diatom cells $(<10 \mu \mathrm{m})$, consistent with the finding of Neukermans et al. (2016). However, if $\mathrm{NO}_{3}{ }^{-}$ concentrations increase, diatoms can become dominant when $\mathrm{Si}(\mathrm{OH})_{4}$ is available. Li et al. (2009) suggested that increased freshwater input to the Arctic is resulting in greater stratification and lower nutrient availability and that the abundance of smaller phytoplankton is increasing (i.e., phytoplankton communities are shifting toward smaller cells). Our data support a shift toward smaller cells at lower nutrient availability whether stratification increases or not.

\section{Heterotrophic Prokaryote Response to Added $\mathrm{NO}_{3}{ }^{-}$}

In contrast to the phytoplankton communities, the heterotrophic prokaryote community showed only limited evidence of $\mathrm{N}$ limitation. While some treatment differences were noted (e.g., higher $\mathrm{BA}$ and $\mathrm{BP}$ in the $\mathrm{NO}_{3}^{-}$treatment relative to the 
control at Stns. 73 and 101, respectively), these differences were small. Evidence of $\mathrm{N}$ limitation within heterotrophic prokaryote communities in the Arctic is scarce. Ortega-Retuerta et al. (2012) reported that the heterotrophic prokaryotic communities in the Chukchi Sea were either N or N/C co-limited during the summers of 2009 and 2010, the latter year as part of the 2010 ICESCAPE expedition. The majority of studies in the Arctic have identified $\mathrm{C}$ as the primary factor limiting heterotrophic prokaryotes (Middelboe and Lundsgaard, 2003; Meon and Amon, 2004; Kirchman et al., 2005; Vallieres et al., 2008; Cuevas et al., 2011). Our study was conducted in the same region as some of those in Ortega-Retuerta et al. (2012) and used the similar methods for measuring BA and BP, yet we saw little evidence of heterotrophic prokaryote $\mathrm{N}$ limitation. One difference was that in the present study, the samples were pre-screened using $100 \mu \mathrm{m}$ mesh to remove large grazers, while in Ortega-Retuerta et al. (2012), a $25 \mu \mathrm{m}$ mesh was used to remove both macro- and micrograzers. Thus, the lack of $\mathrm{N}$ limitation in the heterotrophic prokaryote community we saw could be the result of micrograzers $25-100 \mu \mathrm{m}$ being present in our incubations. Additionally, while we amended the DIN deplete seawater with $\mathrm{NO}_{3}{ }^{-}$, Ortega-Retuerta et al. (2012) used an equal mixture of $\mathrm{NH}_{4}{ }^{+}+\mathrm{NO}_{3}{ }^{-}$, but not $\mathrm{NO}_{3}{ }^{-}$alone. Allen et al. (2005) noted that while some heterotrophic prokaryotes contain assimilatory $\mathrm{NO}_{3}{ }^{-}$reductase genes, others do not. We did measure some increases in the $0.2-1 \mu \mathrm{m}$ particulate organic pool and $\mathrm{NO}_{3}{ }^{-}$uptake rates in the amended treatments, suggesting that the prokaryotes in our incubations did use $\mathrm{NO}_{3}{ }^{-}$. However, the increases were small and perhaps only a portion of the prokaryote community was able to use $\mathrm{NO}_{3}{ }^{-}$ for growth (the vast majority of the prokaryote community can assimilate $\mathrm{NH}_{4}{ }^{+}$or DON). Finally, their experiments were conducted in the dark over $48 \mathrm{~h}$ while ours were conducted at $50 \%$ of incident irradiance, suggesting that when phytoplankton are present and active, they outcompete prokaryotes for $\mathrm{NO}_{3}{ }^{-}$. Thus, differences in light environments, grazing pressure, and/or available $\mathrm{N}$ substrates likely account for the observed differences between the present study and Ortega-Retuerta et al. (2012).

\section{Active Fluorescence}

Nutrient limited phytoplankton show signs of nutrient stress or nutrient starvation (Moore et al., 2013). Nutrient stressed phytoplankton show a physiological response to a nutrient shortage, but may effectively acclimate to their low nutrient environment (Cullen et al., 1992; Parkhill et al., 2001) and still maintain balanced nutrient limited growth. In this case, the cellular concentrations of compounds requiring the limiting nutrient decrease while the cellular concentrations of the compounds not requiring the limiting nutrient are adjusted until production of all cellular constituents has the same nutrient-limited rate averaged over the photocycle. In contrast, when nutrient starved, phytoplankton are deficient in a specific nutrient (or nutrients in the case of co-limitation) and thus stoichiometrically lack one element (e.g., N) relative to another (e.g., P). Under starved conditions (Moore et al., 2013) cells can no longer maintain balanced growth because cellular constituents are manufactured at variable rates relative to one another averaged over the photocycle. The cells will exhibit significant changes in active fluorescence/growth upon nutrient amendments (Cleveland and Perry, 1987; Kolber et al., 1988).

The dynamics of processing photons through photosystem II has been used as a diagnostic marker to distinguish between phytoplankton nutrient stress and starvation. Parkhill et al. (2001) showed that $F_{\mathrm{v}}: F_{\mathrm{m}}$ of the diatom Thalassiosira pseudonana was insensitive to nutrient stress when grown at different steady state (balanced) growth rates and under different irradiances and inferred that the cells were stressed by, but had acclimated to, the low nutrient concentrations. Similarly, a lack of $F_{\mathrm{v}}: F_{\mathrm{m}}$ sensitivity to $\mathrm{N}$-limitation was seen in cyanobacteria-dominated North Atlantic waters that were amended with inorganic N (Moore et al., 2008), suggesting that these populations were stressed, but in balanced growth and acclimated or adapted to the oligotrophic environment. Suggett et al. (2009) noted that $F_{\mathrm{v}}: F_{\mathrm{m}}$ and $\sigma_{\mathrm{PSII}}$ typically remain constant when phytoplankton grow logarithmically, further evidence that fluorescence parameters are insensitive to nutrients under balanced growth. Once a nutrient eventually becomes deficient, a decrease in $F_{\mathrm{v}}: F_{\mathrm{m}}$ and an increase in $\sigma_{\mathrm{PSII}}$ is regularly observed, a sign that cells are starved and that growth is becoming unbalanced.

In the present study, $\mathrm{NO}_{3}{ }^{-}$-driven changes in photophysiology were detected using active fluorescence, but the changes were not the same across all sites. There were clear increases in $F_{\mathrm{v}}: F_{\mathrm{m}}$ at Stns. 73, 101, and 152, which were consistent with the significant increases in phytoplankton biomass in the $\mathrm{NO}_{3}{ }^{-}$treatment at these stations. The increase in $F_{\mathrm{v}}: F_{\mathrm{m}}$ upon $\mathrm{N}$ addition is consistent with $\mathrm{N}$-starved lab cultures of the diatom Phaeodactylum tricornutum (Geider et al., 1993), but not consistent with previous field studies which concluded that phytoplankton that are acclimated to oligotrophic environments are potentially nutrient-stressed, but not starved (Behrenfeld et al., 2006; Moore et al., 2006). One suggestion for a lowered $F_{\mathrm{v}}: F_{\mathrm{m}}$ under $\mathrm{N}$ limitation is that cells allocate less $\mathrm{N}$ toward photosynthetic enzymes (Yentsch and Vaccaro, 1958; Shimura and Fujita, 1975; Kolber et al., 1988; Falkowski et al., 1989; Plumley and Schmidt, 1989). N is an important component of photosystem proteins and low concentrations have been connected to lower concentrations of the photosynthetic reaction center D1 protein (Kolber et al., 1988). Likewise, a recent proteomic study found that multiple proteins involved in chlorophyll synthesis were significantly lower in abundance when the diatom T. pseudonana became N-limited (Hockin et al., 2012). Transcript levels for T. pseudonana genes encoding chlorophyll biosynthesis were also decreased under $\mathrm{N}$ limitation (Mock et al., 2008). The lower $F_{\mathrm{v}}: F_{\mathrm{m}}$ observed here in the control relative to the $\mathrm{NO}_{3}{ }^{-}$treatments supports the idea that the summertime phytoplankton community in the Chukchi Sea is $\mathrm{N}$-starved and likely not in balanced growth.

In addition to a higher $F_{\mathrm{v}}: F_{\mathrm{m}}$ in the $+\mathrm{NO}_{3}{ }^{-}$treatment in these three experiments, $1 / \tau_{\mathrm{QA}}$, was also elevated, lending further support to the idea of $\mathrm{N}$-starvation of the phytoplankton community. In fact, $1 / \tau_{\mathrm{QA}}$ was higher in the $+\mathrm{NO}_{3}{ }^{-}$treatment 
at the final time point in all but the experiment in ACC waters (Stn. 152), although at preceding time points, the turnover rate was elevated above the control at this site as well. Phototrophs can increase the rate of electron flow by either decreasing their antennae size (i.e., $\sigma_{\text {PSII }}$ ), so that electrons spend less time in the pigment bed before reaching reaction centers, or increasing the number of reaction centers (Behrenfeld et al., 1998; Moore et al., 2006; Falkowski and Raven, 2007; Suggett et al., 2010). In the present work, we recorded a corresponding decrease in $\sigma_{\text {PSII }}$ and an increase in $1 / \tau_{\mathrm{QA}}$ in response to $\mathrm{NO}_{3}{ }^{-}$at only Stn. 73. At all other sites where $1 / \tau_{\mathrm{QA}}$ increased due to the $\mathrm{N}$ amendment, either no change or a slight increase in $\sigma_{\text {PSII }}$ was observed. These results suggest that under the depleted ambient DIN concentrations in the Chukchi Sea during our summertime study, the in situ phytoplankton communities lacked $\mathrm{N}$ for the repair of damaged or construction of new reaction centers. $\mathrm{N}$ amendments likely relieved this $\mathrm{N}$ deficit and resulted in the synthesis of more reaction centers and an increase in both $F_{\mathrm{v}}: F_{\mathrm{m}}$ and $1 / \tau_{\mathrm{QA}}$.

In contrast to these sites, no significant differences in the fluorescence parameters were detected between the control and $\mathrm{NO}_{3}{ }^{-}$-treated waters at the Bering Strait site (Stn. 8). This is likely due to the fact that $\mathrm{NO}_{3}{ }^{-}$was not depleted at this site, and thus the in situ phytoplankton community was neither $\mathrm{N}$-starved nor $\mathrm{N}$-limited at the start of our experiment. This is supported by a similar level of biomass accumulation (i.e., POC and PON accumulation) in both the control and $\mathrm{NO}_{3}{ }^{-}$ treatments (Figures 3M,S). It should be noted that despite non-limiting $\mathrm{NO}_{3}{ }^{-}$concentrations at $T=0$ and the similar increase in biomass, there was some evidence suggesting that at the end of the incubation, the control was beginning to experience $\mathrm{N}$-limitation, based on the leveling off of Chl $a$ concentration and a higher $\mathrm{NO}_{3}{ }^{-}$uptake rate in the control.

Our data support $\mathrm{N}$ limitation of the phytoplankton community in the Chukchi Sea, and thus the changes in photophysiology we detected were likely related to nutrient starvation and not stress (i.e., cells were not acclimated or adapted to the nutrient deplete conditions as observed previously in the North Atlantic by Moore et al., 2008). However, caution must be taken when assuming fluorescence changes are a diagnostic for nutrient-stressed cells because fluorescence can differ between taxa. For example, cyanobacteria such as Synechococcus can have lower $F_{\mathrm{v}}: F_{\mathrm{m}}$ than diatoms growing under the same conditions. Likewise, $\sigma_{\text {PSII }}$ variability can range two-threefold between taxa (Suggett et al., 2009), even within broad taxonomic groupings (e.g., diatoms). The simultaneous increases in $\sigma_{\mathrm{PSI}}$ and $1 / \tau_{\mathrm{QA}}$ at Stn. 101 are likely an indicator of a changing taxonomic community. As Figure 5 indicates, the initial community consisted of a significant dinoflagellate component with few diatoms. At the end of the incubation the dinoflagellates had disappeared in both the control and $\mathrm{NO}_{3}{ }^{-}$treatment and diatoms were a greater fraction of the community biomass in the $\mathrm{NO}_{3}{ }^{-}$ treatment, but not in the controls. Thus, while the greater rate of electron turnover $\left(1 / \tau_{\mathrm{QA}}\right)$ in the $\mathrm{NO}_{3}{ }^{-}$treatment indicates the likely repair or new construction of PSII reaction centers, the simultaneous increase in $\sigma_{\text {PSII }}$ suggests that the change in community composition also contributed to the fluorescence response.

\section{$\mathrm{NO}_{3}$ - Uptake Rates}

Our $\mathrm{NO}_{3}{ }^{-}$uptake rates in the Chukchi Sea are within the range of measurements made previously in the Arctic Ocean. On the low end, Lee and Whitledge (2005) measured Canada Basin summertime $\mathrm{NO}_{3}{ }^{-}$uptake rates for phytoplankton beneath ice floes and in the open water as low as $0.021 \pm 0.015$ and $0.072 \pm 0.072 \mathrm{mmol} \mathrm{N} \mathrm{m}^{-3} \mathrm{~d}^{-1}$, respectively. At the high end, $\mathrm{NO}_{3}{ }^{-}$uptake rates span three orders of magnitude, from $\sim 2$ to $150 \mathrm{mmol} \mathrm{N} \mathrm{m}^{-3} \mathrm{~d}^{-1}$ (Smith, 1993, 1995; Kristiansen et al., 1994; Smith et al., 1997; Fouilland et al., 2007). Our initial uptake rates varied by two orders of magnitude $\left(0.01-1.0 \mathrm{mmol} \mathrm{N} \mathrm{m}^{-3}\right.$ $\left.\mathrm{d}^{-1}\right)$. The lowest shelf rates we measured were at the coastal site (Stn. 152) while the highest rates were in Bering Strait (Table 1). The two off-shelf sites, which were most like the Canada Basin sites sampled by Lee and Whitledge (2005), did not have similar rates. The shallower site (Stn. 101) had higher $\mathrm{NO}_{3}{ }^{-}$uptake rates $\left(0.2 \pm 0.016 \mathrm{mmol} \mathrm{N} \mathrm{m}^{-3} \mathrm{~d}^{-1}\right)$ than the deeper site (Stn. 128, $0.01 \pm 0.002 \mathrm{mmol} \mathrm{N} \mathrm{m}^{-3} \mathrm{~d}^{-1}$ ), where concentrations of $\mathrm{NO}_{3}{ }^{-}$ were detectable. Variability in $\mathrm{NO}_{3}{ }^{-}$uptake rates have been most commonly related to temperature, light, and ambient macro- and micronutrient concentrations (Mulholland and Lomas, 2008). In our study, we saw no statistical relationships between the initial $\mathrm{NO}_{3}{ }^{-}$uptake rates and these three environmental variables. Similarly, Baer et al. (2017) was unable to relate $\mathrm{N}$ uptake rates to ambient nutrient concentrations. However, we note that the highest rate of $\mathrm{NO}_{3}{ }^{-}$uptake in the present study was measured at the Bering Strait site, which had the highest in situ $\mathrm{NO}_{3}{ }^{-}$ concentration.

Together, the $\mathrm{NO}_{3}{ }^{-}$uptake rates and changes in particulate concentrations (both POC and PON) in the $<1 \mu \mathrm{m}$ fraction indicate that heterotrophic prokaryotes (Bacteria and/or Archaea) utilize $\mathrm{NO}_{3}{ }^{-}$in the Chukchi Sea, and in some sites significantly (e.g., Stns. 46, 101, 128, and 152). Uptake of $\mathrm{NO}_{3}{ }^{-}$ by prokaryotes is not a surprise, as previous work suggests that both cyanobacteria and heterotrophic prokaryotes can be significant consumers of $\mathrm{NO}_{3}^{-}$(Ortega-Retuerta et al., 2012). Allen et al. (2001) measured $\mathrm{NO}_{3}{ }^{-}$uptake by bacteria in the Barents Sea and of the 30 bacterial isolates collected, 17 contained the bacterial assimilatory $\mathrm{NO}_{3}{ }^{-}$reductase gene $n a s A$, and were able to grow on $\mathrm{NO}_{3}{ }^{-}$as the sole $\mathrm{N}$ source. The nas A-containing isolates were responsible for 17-36\% of total $\mathrm{NO}_{3}{ }^{-}$uptake, higher percentages than measured for total $\mathrm{NH}_{4}{ }^{+}$ uptake (Allen et al., 2001). Likewise, uptake by heterotrophic prokaryotes was higher the farther north they sampled, as well as near the marginal ice zone. Additionally, in the coastal waters near Barrow, Alaska, both the LNA and HNA subpopulations of the heterotrophic prokaryote community were shown to take up $\mathrm{NO}_{3}{ }^{-}$, with the HNA subpopulation having higher rates than the LNA subpopulation (Baer, 2013).

Here, we found that $\mathrm{NO}_{3}{ }^{-}$uptake rates by the $<1 \mu \mathrm{m}$ size fraction were a more variable percentage of the total $\mathrm{N}$ community uptake rates across the study region than detected by Allen et al. (2001). Average $\mathrm{NO}_{3}{ }^{-}$uptake rates by the $<1 \mu \mathrm{m}$ 
fraction were $37 \pm 42$ and $26 \pm 23 \%$ of total community uptake rates in the control and $\mathrm{NO}_{3}{ }^{-}$treatments, respectively. Likewise, there was no latitudinal trend in the relative importance of the $<1 \mu \mathrm{m}$ fraction to total $\mathrm{NO}_{3}{ }^{-}$uptake. Finally, we were unable to partition $\mathrm{NO}_{3}{ }^{-}$uptake in the $<1 \mu \mathrm{m}$ size fraction between the LNA and HNA groups, and we found little difference between the control and treated bottles in the relative proportion of HNA cells. The fact that changes in \%HNA were the same in both the control and $\mathrm{NO}_{3}{ }^{-}$-amended bottles suggests that the $\mathrm{NO}_{3}{ }^{-}$ amendment did not enhance $\mathrm{NO}_{3}{ }^{-}$uptake in either group.

\section{CONCLUSION}

Our data indicate that the summertime phytoplankton community in the Chukchi Sea is N-limited and that the availability of $\mathrm{N}$ at this time of year is unrelated to salinity. More likely, denitrification drives $\mathrm{N}$ from the system, and phytoplankton $\mathrm{N}: \mathrm{P}$ utilization ratios are such that $\mathrm{N}$ is consumed prior to other nutrients. Ultimately, the depleted summertime $\mathrm{N}$ environment results in a phytoplankton community dominated by smaller cells. Transient input of DIN would likely increase the growth of larger diatom cells. Future changes in the Arctic, such as enhanced stratification, which decreases nutrient availability in surface waters will likely result in a continued shift toward smaller celled phytoplankton populations. However, such a shift would also likely result in productivity and export decreases to the sediments, and thus lower rates of denitrification. This negative feedback could enhance $\mathrm{N}$ availability, reduce $\mathrm{N}$ limitation of the phytoplankton, and shift the summer phytoplankton community toward larger cells. Alternative predictions suggest the decrease in Arctic ice cover will result in greater wind driven mixing of the

\section{REFERENCES}

Allen, A. E., Booth, M. G., Frischer, M. E., Verity, P. G., Zehr, J. P., and Zani, S. (2001). Diversity and detection of nitrate assimilation genes in marine bacteria. Appl. Environ. Microbiol. 67, 5343-5348. doi: 10.1128/AEM.67.11.5343-5348. 2001

Allen, A. E., Booth, M. G., Verity, P. G., and Frischer, M. E. (2005). Influence of nitrate availability on the distribution and abundance of heterotrophic bacterial nitrate assimilation genes in the Barents Sea during summer. Aquat. Microb. Ecol. 39, 247-255. doi: 10.3354/ame039247

Ardyna, M., Babin, M., Gosselin, M., Devred, E., Rainville, L., and Tremblay, J.É. (2014). Recent Arctic Ocean sea ice loss triggers novel fall phytoplankton blooms. Geophys. Res. Lett. 41, 6207-6212. doi: 10.1002/2014GL061047

Ardyna, M., Gosselin, M., Michel, C., Poulin, M., and Tremblay, J. É. (2011). Environmental forcing of phytoplankton community structure and function in the Canadian High Arctic: contrasting oligotrophic and eutrophic regions. Mar. Ecol. Prog. Ser. 442, 37-57. doi: 10.3354/meps09378

Armstrong, F. A. J., Stearns, C. R., and Strickland, J. D. H. (1967). The measurement of upwelling and subsequent biological processes by means of the Technicon AutoAnalyzer ${ }^{\mathrm{TM}}$ and associated equipment. Deep Sea Res. 14, 381-389.

Arrigo, K. R., Mills, M. M., van Dijken, G. L., Lowry, K. E., Pickart, R. S., and Schlitzer, S. (2017). Late spring nitrate distributions beneath the ice-covered northeastern Chukchi Shelf. J/ Geophys. Res. 122, 2408-2417. doi: 10.1002/ 2017JG003881

Arrigo, K. R., Perovich, D. K., Pickart, R. S., Brown, Z. W., van Dijken, G. L., Lowry, K. E., et al. (2012). Massive phytoplankton blooms under the Arctic sea ice. Science 336:1408. doi: 10.1126/science.1215065 surface ocean (Martini et al., 2014), reducing stratification, and increase injection of dissolved $\mathrm{N}$ to the surface ocean that will enhance phytoplankton productivity. This enhanced production would then likely increase denitrification rates and potentially decrease the ocean $\mathrm{N}$ inventory.

\section{AUTHOR CONTRIBUTIONS}

MM, ZB, and KA conceived and designed the research. All authors contributed to the collection of and processing of samples and data. Specifically, SL was responsible for the phytoplankton abundance and composition work. EO-R was responsible for all heterotrophic prokaryote work. Then manuscript was written by $\mathrm{MM}$ and KA with editorial input from all authors.

\section{FUNDING}

Fieldwork and analysis for the ICESCAPE program was supported by Ocean Biology and Biogeochemistry Program of the National Aeronautic and Space Administration under Grant No. NNX10AF42G to KA.

\section{ACKNOWLEDGMENTS}

We would like to acknowledge the captain, crew, and science party of the USCGC Healy for their contributions during cruise HLY1101. We thank S. Martin and A. Santiago for their help collecting and processing samples at sea, as well as, Z. Kolber for loaning us the FRRf.

Arrigo, K. R., Perovich, D. K., Pickart, R. S., Brown, Z. W., van Dijken, G. L., Lowry, K. E., et al. (2014). Phytoplankton blooms beneath the sea ice in the Chukchi Sea. Deep Sea Res. Part II Top. Stud. Oceanogr. 105, 1-16. doi: 10.1126/science. 1215065

Arrigo, K. R., and van Dijken, G. L. (2015). Continued increases in Arctic Ocean primary production. Prog. Oceanogr. 136, 60-70. doi: 10.1016/j.pocean.2015. 05.002

Baer, S. E. (2013). Seasonal Nitrogen Uptake and Regeneration in the Water Column and sea-ice of the Western Coastal Arctic. Ph.D. thesis, The College of William and Mary, Williamsburg, VA.

Baer, S. E., Sipler, R. E., Roberts, Q. N., Yager, P. L., Frischer, M. E., and Bronk, D. A. (2017). Seasonal nitrogen uptake and regeneration in the western coastal Arctic. Limnol. Oceanogr. 62, 2463-2479. doi: 10.1002/lno.10580

Behrenfeld, M. J., Prasil, O., Kolber, Z. S., Babin, M., and Falkowski, P. G. (1998). Compensatory changes in photosystem II electron turnover rates protect photosynthesis from photoinhibition. Photosynth. Res. 58, 259-268. doi: 10. 1023/A:1006138630573

Behrenfeld, M. J., Worthington, K., Sherrell, R. M., Chavez, F. P., Strutton, P., McPhaden, M., et al. (2006). Controls on tropical Pacific Ocean productivity revealed through nutrient stress diagnostics. Nature 442, 1025-1028. doi: 10. 1038/nature05083

Berges, J. A., and Falkowski, P. G. (1998). Physiological stress and cell death in marine phytoplankton: induction of proteases in response to nitrogen or light limitation. Limnol. Oceanogr. 43, 129-135. doi: 10.4319/lo.1998.43.1. 0129

Bernhardt, H., and Wilhelms, A. (1967). The continuous determination of low level iron, soluble phosphate and total phosphate with the AutoAnalyzer ${ }^{\mathrm{TM}}$. Technicon. Symp. 1:386. 
Brown, Z. W., Casciotti, K. L., Pickart, R. S., Swift, J. H., and Arrigo, K. R. (2015). Aspects of the marine nitrogen cycle of the Chukchi Sea shelf and Canada Basin. Deep Sea Res. Part II Top Stud. Oceanogr. 118, 73-87. doi: 10.1016/j.dsr2.2015. 02.009

Chang, B. X., and Devol, A. H. (2009). Seasonal and spatial patterns of sedimentary denitrification rates in the Chukchi sea. Deep Sea Res. Part II Top. Stud. Oceanogr. 56, 1339-1350. doi: 10.1016/j.dsr2.2008. 10.024

Cleveland, J. S., and Perry, M. J. (1987). Quantum yield, relative specific absorbtion and fluorescence in nitrogen-limited Chaetoceros gracilis. Mar. Biol. 94, 489-497. doi: 10.1007/BF00431395

Cuevas, L. A., Egge, J. K., Thingstad, T. F., and Topper, B. (2011). Organic carbon and mineral nutrient limitation of oxygen consumption, bacterial growth and efficiency in the Norwegian Sea. Polar Biol. 34, 871-882. doi: 10.1007/s00300010-0944-3

Cullen, J. J., and Davis, R. F. (2003). The blank can make a big difference in oceanographic measurements. Limnol. Oceanogr. Bull. 12, 29-35. doi: 10.1002/ lob.200312229

Cullen, J. J., Yang, X., and MacIntyre, H. L. (1992). "Nutrient limitation of marine photosynthesis," in Preliminary Productivity and Biogeochemical Cycles in the Sea, eds P. G. Falkowski and A. D. Woodhead (Berlin: Springer), 69-88. doi: 10.1007/978-1-4899-0762-2_5

Devol, A. H., Codispoti, L. A., and Christensen, J. P. (1997). Summer and winter denitrification rates in western Arctic shelf sediments. Cont. Shelf Res. 17, 1029-1033. doi: 10.1016/S0278-4343(97)00003-4

Falkowski, P. G., and Raven, J. A. (2007). Aquatic Photosynthesis, 2nd Edn. Princeton, NJ: Princeton Univ. Press.

Falkowski, P. G., Sukenik, A., and Herzig, R. (1989). Nitrogen limitation in Isochrysis galbana (Haptophyceae). 2. Relative abundance of chloroplast proteins. J. Phycol. 25, 471-478. doi: 10.1016/j.gene.2014.04.022

Fouilland, E., Gosselin, M., Rivkin, R. B., Vasseur, C., and Mostajir, B. (2007). Nitrogen uptake by heterotrophic bacteria and phytoplankton in Arctic surface waters. J. Plankton Res. 29, 369-376. doi: 10.1093/femsec/fiy150

Gasol, J. M., and Del Giorgio, P. A. (2000). Using flow cytometry for counting natural planktonic bacteria and understanding the structure of planktonic bacterial communities. Sci. Mar. 64, 197-224. doi: 10.3989/scimar.2000. $64 \mathrm{n} 2197$

Geider, R. J., Laroche, J., Greene, R. M., and Olaizola, M. (1993). Response of the photosynthetic apparatus of Phaeodactylum-tricornutum (Bacillariophyceae) to nitrate, phosphate, or iron starvation. J. Phycol. 29, 755-766. doi: 10.1111/j. 0022-3646.1993.00755.x

Glibert, P. M., and Capone, D. G. (1993). "Mineralization and assimilation in aquatic, sediment, and wetland systems," in Nitrogen Isotope Techniques, eds R. Knowles and T. H. Blackburn (Cambridge, MA: Academic Press), 243-272.

Gong, D., and Pickart, R. S. (2015). Summertime circulation in the eastern Chukchi Sea. Deep Sea Res. Part II Top. Stud. Oceanogr. 118, 18-31. doi: 10.1016/j.dsr2. 2015.02.006

Gong, D., and Pickart, R. S. (2016). Early summer water mass transformation in the eastern Chukchi Sea. Deep Sea Res. Part II Top. Stud. Oceanogr. 130, 43-55. doi: 10.1016/j.dsr2.2016.04.015

Hameedi, M. J. (1978). Aspects of water column primary productivity in the Chukchi Sea during summer. Mar. Biol. 48, 37-48. doi: 10.1007/BF00390529

Hildebrand, M., and Dahlin, K. (2000). Nitrate transporter genes from the diatom Cylindrotheca fusiformis (Bacillariophyceae): mRNA levels controlled by nitrogen source and by the cell cycle. J. Phycol. 36, 702-713. doi: 10.1046/j. 1529-8817.2000.99153.x

Hockin, N. L., Mock, T., Mulholland, F., Kopriva, S., and Malin, G. (2012). The response of diatom central carbon metabolism to nitrogen starvation is different from that of green algae and higher plants. Plant Physiol. 158, 299-312. doi: 10.1104/pp.111.184333

Holm-Hansen, O., Lorenzen, C. J., Holmes, R. W., and Strickland, J. D. H. (1965). Fluormetric Determination of Chlorophyll. ICES J. Mar. Sci. 30, 3-15. doi: 10.1093 /icesjms/30.1.3

Kattner, G., and Budeus, G. (1997). Nutrient status of the Northeast Water Polynya. J. Mar. Syst. 10, 185-197. doi: 10.1016/S0924-7963(96)00070-X

Kerouel, R., and Aminot, A. (1997). A fluorometric determination of ammonia in seas and estuarine waters by direct segmented flow analysis. Mar. Chem. 57, 265-275. doi: 10.1016/S0304-4203(97)00040-6
Kirchman, D. L. (1993). "Leucine incorporation as a measure of biomass production by heterotrophic bacteria," in Handbook of Methods in Aquatic Microbial Ecology, eds P. F. Kemp, B. F. Sherr, E. B. Sherr, and J. J. Cole (Boca Raton, FL: CRC Press), 509-512.

Kirchman, D. L., Malmstrom, R. R., and Cottrell, M. T. (2005). Control of bacterial growth by temperature and organic matter in the Western Arctic. Deep Sea Res. Part II Top. Stud. Oceanogr. 52, 3386-3395. doi: 10.1016/j.dsr2.2005. 09.005

Knap, A., Michaels, A., Close, A., Ducklow, H., and Dickson, A. (eds) (1996). Protocols for the Joint Global Flux Study (JGOFS) core measurements. Paris: UNESCO, 170.

Kolber, Z., Zehr, J., and Falkowski, P. G. (1988). Effects of growth irradiance and nitrogen limitation on photosynthetic energy conversion in photosystem II. Plant Physiol. 88, 72-79. doi: 10.1104/pp.88.3.923

Kristiansen, S., Farbrot, T., and Wheeler, P. A. (1994). Nitroegen cycling in the Berrants Sea- Seasonal dynamics of new and regenerated production in the marginal ice-zone. Limnol. Oceanogr. 39, 1630-1642. doi: 10.4319/lo.1994.39. 7.1630

Laney, S. R., and Sosik, H. M. (2014). Phytoplankton assemblage structure in and around a massive under-ice bloom in the Chukchi Sea. Deep Sea Res. Part II Top. Stud. Oceanogr. 105, 30-41. doi: 10.1016/j.dsr2.2014.03.012

Lee, S. H., and Whitledge, T. R. (2005). Primary and new production in the deep Canada Basin during summer 2002. Polar Biol. 28, 190-197. doi: 10.1007/ s00300-004-0676-3

Lee, S. H., Yun, M. S., Kim, B. K., Joo, H. T., Kang, S.-H., Kang, C. K., et al. (2013). Contribution of small phytoplankton to total primary production in the Chukchi Sea. Cont. Shelf Res. 68, 43-50. doi: 10.1016/j.csr.2013.08.008

Lewis, K. M., Arnsten, A. E., Joy-Warren, H., Lowry, K. E., Mills, M. M., van Dijken, G. L., et al. (2018). Photoacclimation of Arctic Ocean phytoplankton to shifting light and nutrient limitation. Limnol. Oceanogr. 9999, 1-18. doi: 10.1002/lno.11039

Li, W. K. W., McLaughlin, F. A., Lovejoy, C., and Carmack, E. C. (2009). Smallest algae thrive as the Arctic Ocean freshens. Science 326, 539-539. doi: 10.1126/ science. 1179798

Lowry, K. E., Pickart, R. S., Mills, M. M., Brown, Z. W., Dijken, G. L., Bates, N. R., et al. (2015). The influence of winter water on phytoplankton blooms in the Chukchi Sea. Deep Sea Res. Part II Top. Stud. Oceanogr. 118, 53-72. doi: 10.1016/j.dsr2.2015.06.006

Lowry, K. E., Pickart, R. S., Mills, M. M., Selz, V., Pacini, A., Lewis, K. M., et al. (2018). Under-ice phytoplankton bloom dynamics controlled by spring convective mixing in refreezing leads of open water. J. Geophys. Res. 123, 90-109. doi: 10.1002/2016JC012575

Marie, D., Partensky, F., Jacquet, S., and Vaulot, D. (1997). Enumeration and cell cycle analysis of natural populations of marine picoplankton by flow cytometry using the nucleic acid stain SYBR Green I. Appl. Environ. Microbiol. 63, 186-193.

Martini, K. I., Simmons, H. L., Stoudt, C. A., and Hutchings, J. K. (2014). NearInertial Internal Waves and Sea Ice in the Beaufort Sea. J. Phys. Oceanogr. 44, 2212-2234. doi: 10.1175/JPO-D-13-0160.1

McLaughlin, F. A., and Carmack, E. C. (2010). Deepening of the nutricline and chlorophyll maximum in the Canada Basin interior, 2003-2009. Geophys. Res. Lett. 37:L24602. doi: 10.1029/2010GL045459

Meon, B., and Amon, R. M. W. (2004). Heterotrophic bacterial activity and fluxes of dissolved free amino acids and glucose in the Arctic rivers Ob, Yenisei and the adjacent Kara Sea. Aquat. Microb. Ecol. 37, 121-135. doi: 10.3354/ame 037121

Middelboe, M., and Lundsgaard, C. (2003). Microbial activity in the Greenland Sea: role of DOC lability, mineral nutrients and temperature. Aquat. Microb. Ecol. 32, 151-163. doi: 10.3354/ame032151

Mills, M. M., Brown, Z. W., Lowry, K. E., van Dijken, G. L., Becker, S., Pal, S., et al. (2015). Impacts of low phytoplankton NO3-:PO43- utilization ratios over the Chukchi Shelf, Arctic Ocean. Deep Sea Res. Part II Top. Stud. Oceanogr. 118, 105-121. doi: 10.1016/j.dsr2.2015.02.007

Mock, T., Samanta, M. P., Iverson, V., Berthiaume, C., Robison, M., Holtermann, K., et al. (2008). Whole-genome expression profiling of the marine diatom Thalassiosira pseudonana identifies genes involved in silicon bioprocesses. Proc. Natl. Acad. Sci. U.S.A. 105, 1579-1584. doi: 10.1073/pnas. 0707946105 
Moore, C. M., Mills, M. M., Arrigo, K. R., Berman-Frank, I., Bopp, L., and Boyd, P. W. (2013). Processes and patterns of oceanic nutrient limitation. Nat. Geosci. 6, 701-710. doi: 10.1038/ngeo1765

Moore, C. M., Mills, M. M., Langlois, R., Milne, A., Achterberg, E. P., and La Roche, J. (2008). Relative influence of nitrogen and phosphorus availability on phytoplankton physiology and productivity in the oligotrophic sub-tropical North Atlantic Ocean. Limnol. Oceanogr. 53, 291-305. doi: 10.4319/lo.2008.53. 1.0291

Moore, C. M., Suggett, D. J., Hickman, A. E., Kim, Y. N., Tweddle, J., and Sharples, J. (2006). Phytoplankton photoacclimation and photoadaptation in response to environmental gradients in a shelf sea. Limnol. Oceanogr. 51, 936-949. doi: 10.4319/lo.2006.51.2.0936

Mulholland, M. R., and Lomas, M. W. (2008). "Nitrogen uptake and assimilation," in Nitrogen in the Marine Environment, 2nd Edn, eds D. Capone, D. A. Bronk, M. R. Mulholland, and E. J. Carpenter (Cambridge, MA: Academic Press), 303-384. doi: 10.1016/B978-0-12-372522-6. 00007-4

Neukermans, G., Reynolds, R. A., and Stramski, D. (2016). Optical classification and characterization of marine particle assemblages within the western Arctic Ocean. Limnol. Oceanogr. 61, 1472-1494. doi: 10.1002/lno. 10316

Olson, R. J. and Sosik, H. M. (2007). A submersible imaging-in-flow instrument to analyze nano-and microplankton: imaging FlowCytobot. Limnol. Oceanogr. Methods 5, 195-203. doi: 10.4319/lom.2007.5.195

Ortega-Retuerta, E., Jeffrey, W. H., Ghiglione, J. F., and Joux, F. (2012). Evidence of heterotrophic prokaryotic activity limitation by nitrogen in the Western Arctic Ocean during summer. Polar Biol. 35, 785-794. doi: 10.1007/s00300-0111109-8

Pabi, S., van Dijken, G. L., and Arrigo, K. R. (2008). Primary production in the Arctic Ocean, 1998-2006. J. Geophys. Res. Oceans 113,

Palmer, M. A., Van Dijken, G. L., Mitchell, B. G., Seegers, B. J., Lowry, K. E., and Mills, M. M. (2013). Light and nutrient control of photosynthesis in natural phytoplankton populations from the Chukchi and Beaufort seas, Arctic Ocean. Limnol. Oceanogr. 58, 2185-2205. doi: 10.4319/lo.2013.58.6.2185

Parkhill, J. P., Maillet, G., and Cullen, J. J. (2001). Fluorescence-based maximal quantum yield for PSII as a diagnostic of nutrient stress. J. Phycol. 37, 517-529. doi: 10.1046/j.1529-8817.2001.037004517.x

Perovich, D., Meier, W., Tschudi, M., Farrell, S., Gerland, S., Hendricks, S., et al. (2016). Sea Ice [in Arctic Report Card 2016]. Available at: http://www.arctic. noaa.gov/Report-Card

Perovich, D. K., Jones, K. F., Light, B., Eicken, H., Markus, T., and Stroeve, J. (2011). Solar partitioning in a changing Arctic sea-ice cover. Ann. Glaciol. 52, 192-196. doi: 10.3189/172756411795931543

Perovich, D. K., Light, B., Eicken, H., Jones, K. F., Runciman, K., and Nghiem, S. V. (2007). Increasing solar heating of the Arctic Ocean and adjacent seas, 19792005: attribution and role in the ice-albedo feedback. Geophys. Res. Lett. 34:C7. doi: 10.1029/2007GL031480

Pickart, R. S., Moore, G. W. K., Mao, C. Y., Bahr, F., Nobre, C., and Weingartner, T. J. (2016). Circulation of winter water on the Chukchi shelf in early Summer. Deep Sea Res. Part II Top. Stud. Oceanogr. 130, 56-75. doi: 10.1016/j.dsr2.2016. 05.001

Pickart, R. S., Pratt, L. J., Proshutinsky, A. Y., Torres, D. J., Whitledge, T. E., Aagaard, K., et al. (2010). Evolution and dynamics of the flow through Herald Canyon in the Western Chukchi Sea. Deep Sea Res. Part II 57, 5-26. doi: 10.1016/j.dsr2.2009.08.002

Plumley, F. G., and Schmidt, G. W. (1989). Nitrogen-dependent regulation of photosynthetic gene-expression. Proc. Natl. Acad. Sci. U.S.A. 86, 2678-2682. doi: 10.1073/pnas.86.8.2678

Serreze, M. C., Barrett, A. P., Slater, A. G., Woodgate, R. A., Aagaard, K., Lammers, R. B., et al. (2006). The large-scale freshwater cycle of the Arctic. J. Geophys. Res. Oceans 111:C11010. doi: 10.1111/gcb.12247

Shimura, S., and Fujita, Y. (1975). Changes in activity of fucoxanthin-excited photosynthesis in marine diatom Phaeodactylum tricornutum grown under different culture conditions. Mar. Biol. 33, 185-194. doi: 10.1007/BF00390922

Simpson, K. G., Tremblay, J. E., Gratton, Y., and Price, N. M. (2008). An annual study of inorganic and organic nitrogen and phosphorus and silicic acid in the southeastern Beaufort Sea. J. Geophys. Res. Oceans 113:C07016. doi: 10.1029/ 2007JC004462
Smedsrud, L. H., Halvorsen, M. H., Stroeve, J. C., Zhang, R., and Kloster, K. (2017). Fram Strait sea ice export variability and September Arctic sea ice extent over the last 80 years. Cryosphere 11, 65-79. doi: 10.5194/tc-11-652017

Smith, D. C., and Azam, F. (1992). A simple, economical method for measuring bacterial protein synthesis rates in seawater usin 3H-leucine. Mar. Microb. Food Webs 6, 107-114.

Smith, W. O. (1993). Nitrogen uptake and new production in the Greenland Sea - The spring Phaeocystis bloom. J. Geophys. Res. Oceans 98, 4681-4688. doi: 10.1029/92JC02754

Smith, W. O. (1995). Primary productivity and new production in the Northeast Water (Greenland) Polynya during Summer-1992. J. Geophys. Res. Oceans 100, 4357-4370. doi: 10.1029/94JC02764

Smith, W. O., Gosselin, M., Legendre, L., Wallace, D., Daly, K., and Kattner, G. (1997). New production in the Northeast Water Polynya: 1993. J. Mar. Sys. 10, 199-209. doi: 10.1016/S0924-7963(96)00067-X

Spall, M. A. (2007). Circulation and water mass transformation in a model of the Chukchi Sea. J. Geophys. Res. 112:C05025. doi: 10.1029/2005JC00 3364

Spall, M. A., Pickart, R. S., Brugler, E. T., Moore, G. W. K., Thomas, L., and Arrigo, K. R. (2014). Role of shelfbreak upwelling in the formation of a massive under-ice bloom in the Chkchi Sea. Deep Sea Res. Part II 105, 17-29. doi: 10.1016/j.dsr2.2014.03.017

Spielhagen, R. F., Werner, K., Sørensen, S. A., Zamelczyk, K., Kandiano, E., Budeus, G., et al. (2011). Enhanced modern heat transfer to the Arctic by Warm Atlantic Water. Science 331, 450-453. doi: 10.1126/science.119 7397

Stroeve, J., Holland, M. M., Meier, W., Scambos, T., and Serreze, M. (2007). Arctic sea ice decline: faster than forecast. Geophys. Res. Lett. 34:L09501. doi: 10.1029/ 2007GL029703

Suggett, D. J., Moore, C. M., and Geider, R. J. (2010). Estimating aquatic productivity from active fluorescence measurements. Chlorphyll Fluoresc. Aquat. Sci. Methods Appl. 4, 103-127.

Suggett, D. J., Moore, C. M., Hickman, A. E., and Geider, R. J. (2009). Interpretation of fast repetition rate (FRR) fluorescence: signatures of phytoplankton community structure versus physiological state. Mar. Ecol. Prog. Ser. 376, 1-19. doi: $10.3354 /$ meps07830

Tremblay, J. E., Gratton, Y., Carmack, E. C., Payne, C. D., and Price, N. M. (2002). Impact of the large-scale Arctic circulation and the North Water Polynya on nutrient inventories in Baffin Bay. J. Geophys. Res. Oceans 107:3112. doi: 10. 1029/2000JC000595

Tremblay, J. E., Simpson, K., Martin, J., Miller, L., Gratton, Y., Barber, D., et al. (2008). Vertical stability and the annual dynamics of nutrients and chlorophyll fluorescence in the coastal, southeast Beaufort Sea. J. Geophys. Res. Oceans 113:C07S90. doi: 10.1029/2007JC004547

Tremblay, J. É, and Gagnon, J. (2009). "The effects of irradiance and nutrient supply on the productivity of Arctic waters: a perspective on climate change," in Influence of Climate Change on the Changing Arctic and Sub-Arctic Conditions. NATO Science for Peace and Security Series C: Environmental Security, eds J. C. J. Nihoul and A. G. Kostianoy (Dordrecht: Springer).

Vallieres, C., Retamal, L., Ramlal, P., Osburn, C. L., and Vincent, W. F. (2008). Bacterial production and microbial food web structure in a large arctic river and the coastal Arctic Ocean. J. Mar. Syst. 74, 756-773. doi: 10.1016/j.jmarsys. 2007.12.002

Weingartner, T., Dobbins, E., Danielson, S., Winsor, P., Potter, R., and Statscewich, H. (2013). Hydrographic variability over the northeastern Chukchi Sea shelf in summer-fall 2008-2010. Cont. Shelf Res. 67, 5-22. doi: 10.1016/j.csr. 2013.03.012

Weingartner, T. J., Aagaard, K., Woodgate, R., Danielson, S., Sasaki, Y., and Cavalieri, D. J. (2005). Circulation on the north central Chukchi Sea shelf. Deep Sea Res. Part II 52, 3150-3174. doi: 10.1016/j.dsr2.2005 10.015

Woodgate, R. A., Weingartner, T. J., and Lindsay, R. (2012). Observed increases in Bering Strait oceanic fluxes from the Pacific to the Arctic from 2001 to 2011 and their impacts on the Arctic Ocean water column. Geophys. Res. Lett. 39:L24603. doi: 10.1029/2012GL054092

Yentsch, C. S., and Vaccaro, R. F. (1958). Phytoplankton nitrogen in the oceans. Limnol. Oceanogr. 3, 443-448. doi: 10.4319/lo.1958.3.4.0443 
Yun, M. S., Whitledge, T. E., Stockwell, D., Son, S. H., Lee, J. H., Park, J. W., et al. (2016). Primary production in the Chukchi Sea with potential effects of freshwater content. Biogeosciences 13, 737-749. doi: 10.5194/bg-13-7372016

Zehr, J. P., Falkowski, P. G., Fowler, J., and Capone, D. G. (1988). Coupling of ammonium uptake and incorporation in a marine diatom: experiments with the short-lived radio isotope 13N. Limnol. Oceanogr. 33, 518-527. doi: 10.4319/ lo.1988.33.4.0518

Zhang, J., and Walsh, J. E. (2006). Thermodynamic and hydrological impacts of increasing greenness in northern high latitudes. J. Hydrometeorol. 7, 1147-1163. doi: 10.1175/JHM535.1
Conflict of Interest Statement: The authors declare that the research was conducted in the absence of any commercial or financial relationships that could be construed as a potential conflict of interest.

Copyright (๑) 2018 Mills, Brown, Laney, Ortega-Retuerta, Lowry, van Dijken and Arrigo. This is an open-access article distributed under the terms of the Creative Commons Attribution License (CC BY). The use, distribution or reproduction in other forums is permitted, provided the original author(s) and the copyright owner(s) are credited and that the original publication in this journal is cited, in accordance with accepted academic practice. No use, distribution or reproduction is permitted which does not comply with these terms. 